\title{
Fibrinolytic niche is requested for alveolar type 2 cell-mediated alveologenesis and injury repair
}

Ali Gibran ${ }^{1, \&}$, Runzhen Zhao ${ }^{1, \&}$, Mo Zhang ${ }^{1,2, \&}$, Krishan G. Jain ${ }^{1}$, Jianjun Chang ${ }^{1,3}$, Satoshi Komatsu ${ }^{1}$, Xiaohui Fang $^{4}$, Beiyun Zhou ${ }^{6,7,8,9}$, Jiurong Liang ${ }^{10}$, Dianhua Jiang ${ }^{10}$, Mistuo Ikebe ${ }^{1}$, Michael A Matthay ${ }^{4,5}$, Hong-Long Ji ${ }^{1}$ $11, *$

${ }^{1}$ Department of Cellular and Molecular Biology, University of Texas Health Science Center at Tyler, Tyler, TX, USA $;{ }^{2}$ Institute of Lung and Molecular Therapy, Xinxiang Medical University, Xinxiang, Henan, China; ${ }^{3}$ Institute of Health Sciences, China Medical University, Shenyang, Liaoning, China; ${ }^{4}$ Department of Medicine and Anesthesia, ${ }^{5}$ Cardiovascular Research Institute, University of California San Francisco, San Francisco, CA, USA; ${ }^{6}$ Division of Pulmonary, Critical Care and Sleep Medicine, ${ }^{7}$ Hastings Center for Pulmonary Research, ${ }^{8}$ Norris Comprehensive Cancer Center, ${ }^{9}$ Department of Medicine, Keck School of Medicine, University of Southern California, Los Angeles, CA, USA; ${ }^{10}$ Department of Medicine, Cedars-Sinai Medical Center, Los Angeles, CA, USA; ${ }^{11}$ Texas Lung Injury Institute, University of Texas Health Science Center at Tyler, Tyler, TX, USA.

Running title: Fibrinolysins for alveolar re-epithelialization

\& These authors equally contributed to the study.

\section{* Corresponding authors:}

Hong-Long Ji, James.Ji@uthct.edu 


\section{ABSTRACT}

COVID-19, SARS, and MERS are featured by fibrinolytic dysfunction. To test the role of the fibrinolytic niche in the regeneration of alveolar epithelium, we compared the self-renewing capacity of alveolar epithelial type 2 (AT2) cells and its differentiation to AT1 cells between wild type (wt) and fibrinolytic niche deficient mice (Plau /- and Serpine $\left.{ }^{T g}\right)$. A significant reduction in both proliferation and differentiation of deficient AT2 cells was observed in vivo and in 3D organoid cultures. This decrease was mainly restored by uPA derived A6 peptide, a binding fragment to CD44 receptors. The proliferative and differential rate of CD44 ${ }^{+} \mathrm{AT} 2$ cells was greater than that of CD44- controls. There was a reduction in transepithelial ion transport in deficient monolayers compared to wt cells. Moreover, we found a marked suppression in total AT2 cells and CD $44^{+}$subpopulation in lungs from brain dead patients with acute respiratory distress syndrome (ARDS) and a mouse model infected by influenza viruses. Thus, we demonstrate that the fibrinolytic niche can regulate AT2-mediated homeostasis and regeneration via a novel uPA-A6-CD44+-ENaC cascade.

Keywords: urokinase plasminogen activator, alveolar progenitor epithelial cells, alveologenesis, 3D organotypic culture, polarized monolayer, acute lung injury, alveolar epithelium 


\section{BACKGROUND}

The epithelial lining of regeneratively quiescent lungs is composed of alveolar type 2 (AT2) progenitor and differentiated alveolar type 1 (AT1) cells. To replace aged AT1 cells, AT2 cells undergo self-renewal to maintain alveolar epithelial homeostasis1. The regenerative potential of AT2 cells could be activated for timely recovery from lung epithelial injury2-4, including lobectomy and infections5, 6. A marked suppression in fibrinolytic activity in local respiratory illnesses (e.g., inhaled smoke and aspirated gastric juice) and pulmonary complications of systemic diseases (e.g., sepsis) has been reported clinically and in animal models7 7 . Migration and differentiation of mesenchymal stem cells (MSCs) in inflamed tissues are regulated by dynamic fibrinolytic niche9-12. The proteolysis of extracellular matrix substrates by urokinase plasminogen activator (uPA) could be involved in the benefit of the fibrinolytic niche to the regeneration of skeletal muscles and fractured cartilage1317. For example, uPA and plasmin, two critical components of the fibrinolytic niche, cleave epithelial sodium channels $(\mathrm{ENaC}) 18$, 19. In addition, functionally multifaceted uPA regulates alveolar epithelial function20 and possesses an A6 motif with a high affinity to $\mathrm{CD} 44$ receptors21 $22 . \mathrm{CD}^{+} 4^{+} \mathrm{AT} 2$ cells show a higher proliferative capacity in fibrotic lungs23. The fibrinolytic niche in alveolar epithelial homeostasis and regeneration mediated by AT2 cells, however, has not been studied systematically. Our results have tested the potential novel contribution of uPA-PAI1-A6-CD44-ENaC cascade to the fibrinolytic niche in regulating the fate of AT2 cells.

\section{RESULTS}

Reduced proliferation and differentiation of AT2 cells in injured mouse and human lungs. To examine the effects of fibrinolytic niche on AT2 cells in normal and injured lungs, we infected wt and Plau ${ }^{-/}$mice with the PR8 H1N1 type A influenza virus intranasally24, 25. The severity of injured regions was classified as mild, moderate, and severe based on the lung injury score26. Randomly selected fields were analyzed with the ImageJ software to count proSPC ${ }^{+}$AT2 cells (green) and the total cells for wt (Fig. 1A) and Plau ${ }^{-/-}$mice (Fig. 1B). Although AT1 cells were stained with anti-pdpn antibody, it was not possible to clearly distinguish from other non-epithelial cells, i.e., basal cells, leukocytes, endothelial cells, and fibroblasts due to considerable overlap. 
AT2 cells per field of wt lungs were approximately two-fold $(12.6 \pm 0.55 \%)$ that of Plau ${ }^{-/-}$lung preparations (6.0 $\pm 0.35 \%, \mathrm{n}=26$ from 8 different mice). Moreover, influenza-infected lungs displayed widespread alveolar collapse and increased thickness of the lung interstitial septa in a severity-dependent manner. AT2 cells per field were significantly reduced in both moderate and severe injury regions as compared to wt controls (Fig. 1A-B). Similarly, this finding was observed in Plau $^{-/-}$mice (Fig. 1B-C). AT2 cells per field for Plau ${ }^{-/-}$mice were markedly fewer than in wt animals (Fig. 1C. $\mathrm{n}=9$ mice, 5 fields per mice). This is consistent with a reduction in the yield of total AT2 cells $\left(1.7 \times 10^{6}\right.$ cells for Plau $^{-/-}$mice vs $2.6 \times 10^{6}$ cells for wt mice, Fig. 1D). We compared $\mathrm{CD}_{4} 4^{+}$AT2 cells between healthy and ARDS patients $(\mathrm{n}=3$ patients per group). As shown by fluorescenceactivated cell sorting (FACS) data, CD44+ AT2 cells were reduced in ARDS patients (Fig. 1E-G). These results suggest that Plau $^{-/}$mice may mimic impaired fibrinolytic niches in the lung of ARDS patients.

Plau gene is required for AT2 mediated alveologenesis in vitro. To determine whether the Plau gene is required for re-alveolarization in vitro, we quantified spheroids formed by primary AT2 cells from both wt and Plau ${ }^{-/-}$ mice in parallel (Fig. 2A). Organoids were captured as $4 \times$ DIC images from 4 to 12 days post seeding (Fig. S2). Organoids with a diameter $>50 \mu \mathrm{m}$ (Fig. 2B) and colony forming efficiency (CFE) (Fig. 2C) were significantly decreased $(\mathrm{n}=12, \mathrm{P}<0.01)$ in Plau $^{-/}$cultures compared with wt controls. Apparently, the organoids with a diameter ranging from $50-200 \mu \mathrm{m}$ resulted in a reduction in colonies and CFE (Fig. 2D). The suppression in organoid formation associated with $\mathrm{Plau}^{-/-}$cells contributed to the reduction of total surface area, a clinical parameter for epithelial repair and development (Fig. 2E). The large organoids were filled with culture medium, having a smaller lumen with thicker walls for Plau $^{-/}$cultures over wt controls (Fig. 2F-G). These data provide direct evidence for the regulation of AT2-mediated re-alveologenesis by uPA.

In addition, the organoids were further visualized with cell-permeable green fluorescent calcein to measure the cystic fibrosis transmembrane conductance regulator (CFTR) and ENaC activity (Fig. S3). The surface area was not altered in 30 minutes in the presence of cAMP-elevating forskolin, CFTRinh, and amiloride. One potential explanation is that these organoids do not develop tight junctions intercellularly as well as polarized monolayers. 
Plau gene regulates polarization and bioelectric features of AT2 monolayers. The divergent bioelectric features in polarized AT2 monolayers, including transepithelial resistance $\left(\mathrm{R}_{\mathrm{T}}\right)$ and short-circuit currents (ISC) were measured. Plau ${ }^{-/}$monolayers showed a lower ISC level compared to wt monolayer and diminished significantly by replacing $\mathrm{Na}^{+}$-free bath solution to inhibit $\mathrm{Na}^{+}$ion transport (Fig. 3A-B), consistent with our previous studies in the airway epithelial cells27. Moreover, Plau ${ }^{-/}$AT2 cells showed a reduced amiloridesensitive ISC level compared to wt cells (Fig. 3C-D). However, the amiloride affinity was not altered significantly (Fig. 3D). In addition, a greater $\mathrm{R}_{\mathrm{TE}}$ value on day 5 was measured in wt monolayers compared to Plau $^{-{ }^{-}}$monolayer cultures (Fig. 3E). Thus, the ENaC activity seems to be regulated by the Plau gene.

Plau gene up-regulates the fate of AT2 cells. To quantify AT1 and AT2 cells in colonies, 3D images were obtained by stacking Z sections of each organoid (Fig. S4). Organotypic cultures showed a reduction in the number of epithelial cells in Plau $^{-/-}$organoids as compared to wt cultures (Fig. 4A-C). Similarly, polarized monolayers exhibited a decline in both AT1 and AT2 cells in Plau ${ }^{-/-}$cells, too (Fig. 4D-E). Further, this reduction in AT1, AT2, and total cells in Plau/- monolayers compared to wt cultures was confirmed by FACS (Fig. 4F). Also, cells counted in polarized monolayers showed a similar decline in both AT1 and AT2 cells (Fig. S5A-B). However, there was not a difference in the geometric volume and surface of monolayers between wt and Plau ${ }^{-/}$ cultures (Fig. S5C-E), perhaps due to the analysis of a small portion $\left(0.12 \%, 0.0004 \mathrm{~cm}^{2}\right)$ of entire monolayers $\left(0.33 \mathrm{~cm}^{2}\right)$. These results suggest that Plau regulates the renewal and differentiation of AT2 cells.

Plau gene facilitates DNA synthesis. To analyze DNA synthesis accompanied by cell proliferation, AT2 cells with active DNA synthesis were assessed by the EdU incorporation assays in both monolayers and organoids. Monolayer cultures of Plau ${ }^{-/}$AT2 cells showed significantly lesser EdU ${ }^{+}$cells (Fig. 5A-B). Further, organoids were analyzed with 3D stacking images to count $\mathrm{EdU}^{+}$cells through an entire spheroid (Fig. S6). Plaul- colonies showed a significantly reduced percentage of EdU ${ }^{+}$cells compared with wt controls (Fig. 5C-D). The difference in $\mathrm{EdU}^{+}$cells is in agreement with the diverse proliferative AT2 cells between wt and Plau ${ }^{-/-}$cultures.

The CD44 receptor and the uPA signal pathway involve in alveologenesis. The A6 peptide is derived from the connecting domain of uPA (from aa136 to aa143). The A6 peptide may serve as a mediator for uPA to bind with CD44 receptors located at the plasma membrane of AT2 cells. If so, the application of A6 peptides may 
restore the dysfunctional fate of Plau deficient AT2 cells. A6 peptides but not scramble controls (sA6) significantly increased spheroids (Fig. 6A-B). Also, A6 peptide markedly augmented the surface area of Plau ${ }^{-/-}$ organoids per well $\left(1.35 \pm 0.13 \mathrm{~mm}^{2}\right.$ vs. $0.82 \pm 0.05 \mathrm{~mm}^{2}$ for sA6 group). In addition, blockade of CD44 receptors with a neutralizing antibody reduced wt organoids and corresponding surface area (Fig. S6C). Furthermore, the CD44 antibody resulted in a significant decrease in the number of AT2 cells in addition to a slight reduction in AT1 cells without statistical significance in wt organoids (Fig. 6C, 6E-F). In contrast, the number of both AT1 and AT2 cells was reduced in Plau ${ }^{-/}$organoids (Fig. 6C-F), which were partially restored by A6 peptides. These two sets of experiments demonstrate that the binding of A6 peptides to CD44 receptors mediates the regulation of AT2 fate by uPA.

To corroborate these observations, we sorted and compared CD44+ and CD44- AT2 cells between wt and Plau ${ }^{-/-}$ mice by FACS. CD44 receptors at the AT2 cell surface were recovered for 24 - 36 h post enzymatic isolation. Significantly more CD44 ${ }^{+}$AT2 cells were harvested from wt mice than those from Plau ${ }^{-/-}$mice (Fig. 7A-B). We then cultured the organoids with these sorted $\mathrm{CD}_{4} 4^{+}$and $\mathrm{CD} 44^{-}$cells. Organoids developed by $\mathrm{CD}_{4} 4^{+}, \mathrm{Plau}^{-/-}$ AT2 cells were significantly reduced $\left(112 \pm 10\right.$ organoids vs. $182 \pm 12$ organoids for $\mathrm{CD}^{4} 4^{+}, \mathrm{Plau}^{+/+}$cells $)$. In contrast, there was no significant difference in the number of organoids grown from CD44- AT2 cells between wt and Plau $^{-/-}$groups (30 \pm 1 organoids for wt and $33 \pm 2$ organoids for Plau ${ }^{-/}$line) (Fig. 7C-E). AT1 and AT2 cells in $\mathrm{CD}_{4} 4^{+}$Plau $^{-/-}$organoids were fewer ( $\mathrm{n}=6$ transwells in 3 independent experiments) than wt $\mathrm{CD}_{4} 4^{+}$organoids (Fig. 7F-G). However, a significant decrease was observed only in AT1 but not AT2 cells of CD44- Plau ${ }^{-/-}$ organoids (Fig. 7H). Hence, both in vivo and in vitro data suggest that the Plau gene regulates the fate of CD44 AT2 progenitor cells in vivo and that alveologenesis in vitro is utmost predominately determined by $\mathrm{CD}^{4} 4^{+}$cells. Fibrinolytic activity is required for re-alveolarization and tissue homeostasis. To further substantiate the role of the fibrinolytic niche in lung regeneration, we compared the proliferation and differentiation of AT2 cells between wt and Serpine1 transgenic $\left(P A I-1^{T g}\right)$ mice. Elevated PAI-1 level is a hallmark of lung injury patients2833. Genetically engineered humanized mice expressing a gain-of-function PAI-1 human gene mimicked the disrupted fibrinolytic niche in septic ARDS patients34, 35. Lesser AT2 cells were harvested from $P A I-1^{T g}$ mice 
compared to wt (Fig. 8A). These cells were then sorted for $\mathrm{CD}^{+} 4^{+}$and $\mathrm{CD}^{-} 4^{-}$cells (Fig. 8B). A significant decrease in $\mathrm{CD}_{4} 4^{+}$AT2 cells was observed in PAI- $1^{T g}$ mice, which was similar to that in $P l a u^{-/}$mice (Fig. 8C). Moreover, CD44 ${ }^{+}$AT2 cells of $P A I-1^{T g}$ mice developed fewer organoids than wt controls (61 \pm 9 organoids vs. $91 \pm 7$ organoids for wt controls, $\mathrm{n}=12$ ) (Fig. 8D-E). Correspondingly, the total surface area of organoids of $P A I-$ $1^{T g}$ AT2 cells was significantly reduced compared with wt cultures (Fig. 8F). Further, duplication of $P A I-1^{T g}$ AT2 but not AT1 cells in organoids were down-regulated (Fig. 8G-H). On the other hand, the transepithelial resistance in wt AT2 monolayers was reduced with a maximal difference on day 5 than that in $P A I-1^{T g}$ cultures (Fig. 8I). Basal, amiloride-sensitive, and amiloride-resistant fractions of the short-circuit (ISC) currents in $P A I-1^{T g}$ monolayers were reduced (Fig. 8J). However, the amiloride sensitivity remained unchanged by over-expression of the PAI-1 gene, as shown by apparent $k_{i}$ values (Fig. 8K). Consistent with the results in Plau ${ }^{-/-}$mice and cultures, disruption of the fibrinolytic niche by PAI-1 overexpression attenuates the rate of AT2 cells for renewal and differentiation to AT1 cells.

\section{DISCUSSION}

The primary objective of this study was to decipher the role of the fibrinolytic niche in the re-alveolarization mediated by progenitor AT2 cells and underlying mechanisms in healthy and injured lungs. We employed influenza-infected mice, Plau $^{-/}$and Serpine ${ }^{T g}$ mouse strains, primary human AT2 cells from the human lungs of brain-dead patients with ARDS, and 3D organoids and polarized monolayers of AT2 cells to trace the cell fate in vivo and in vitro. The results demonstrate that the impaired fibrinolytic niche in influenza-infected lungs and genetically engineered mice modeling impaired fibrinolytic niche results in a significant decline in the proliferative AT2 and differentiated AT1 cells.

These results thus demonstrate the novel finding that that the fibrinolytic niche may be critical for realveologenesis. Previous studies suggest that $\mathrm{Plau}^{-/-}$and $P A I-I^{T g}$ mice are more susceptible to lung fibrosis post bleomycin injury36, 37. Clinically, impaired fibrinolytic niche, including elevated PAI-1 contents and suppressed fibrinolytic activity, are prognostic markers for ARDS patients38, 39. Deficiency of plasminogen activators and plasminogen leads to dysfunctional repair of injured tissues (i.e., skin and muscle)40,41. In contrast, regeneration 
of injured muscle is improved by knocking out the Serpinel gene142. The Plau gene regulates the proliferation of various cells, including renal epithelial cells43, 44, umbilical vein endothelial cells45, vascular endothelial cells46, and keratinocytes47, 48. Contrary to this, Serpinel is a negative regulator of cell proliferation through the phosphatidylinositol3-kinase/Akt pathway in endothelial cells49, 50. Our study uncovers a new signaling pathway of the fibrinolytic niche in the AT2 cell-mediated re-alveolarization. The uPA/A6/CD44/ENaC cascade is involved in the regulation of self-renewal and differentiation of mouse and human AT2 cells, particularly the $\mathrm{CD}_{4} 4^{+}$subpopulation. This conclusion was further substantiated in Serpine $1^{T g}$ mice that have a disrupted fibrinolytic niche similar to the Plau $^{-/}$mice, and both mouse lines are reasonable pre-clinical models of ARDS. The proteolytic link between the fibrinolytic niche and $\mathrm{ENaC}$ proteins has been provided by other groups and us in vivo and in vitro27,51-53. The differences between each component of the fibrinolytic niche are described previously. For example, uPA but not tPA cleaves human $\gamma \mathrm{ENaC}$ subunits51. PAI-1 or antiplasmin alone does not affect ENaC activity. The slight diversity between the Plau ${ }^{-/}$and Serpine ${ }^{T g}$ models in this study could be due to their differential regulation of $\mathrm{ENaC}$ and other down-stream molecules.

CD44 is a crucial mediator for the regulation of re-alveologenesis by AT2 cells. We previously demonstrated that CD44 receptors govern cell survival and the progression of lung fibrosis via the Toll-like receptors and hyaluronan54. The connective domain of uPA has an eight L-amino acid sequence (Ac-KPSSPPEE-NH2), known as A6 peptide55. Binding of the A6 peptide with the link domain of CD44 receptors initiates the downstream signaling56. $C D 44^{-/}$mice demonstrate an inflammatory phenotype characterized by increased inflammatory cell recruitment and are more susceptible to LPS induced injury. CD44 deficiency leads to impaired expression of negative regulators of TLR signaling in macrophages, an essential event in the prevention of LPS induced inflammatory responses57. Our study demonstrates a new mechanism that the CD44 receptors at the plasma membrane of AT2 cells are a key player for AT2 cell-mediated re-alveolarization. In addition to the reduction in AT2 cells in injured mouse and human lungs associated with aberrant fibrinolytic niche, both Plau /- and Serpine ${ }^{T g}$ AT2 cells cannot develop organoids equal to those of wt mice in vitro, mostly likely due to the 
lesser expression of CD44 receptors in AT2 cells as A6 peptide compensates for the loss of organoids. This is supported by our previously unreported observations that CD44 $4^{+}$AT2 cells have an enhanced capacity for selfrenewal and differentiation to AT1 cells. Of note, both Plau $^{-/}$and Serpine ${ }^{T g}$ mice have lesser CD44 AT2 cells so that the total yield of primary AT2 cells is significantly reduced compared with wt controls.

The brain ENaC proteins encoded by the Scnnla, $1 b, 1 d$, and $1 g$ are involved in adult neurogenesis by the transmembrane sodium signals for the deletion of Scnn 1 a or functional blockade by amiloride in neural stem cells strongly impairs their proliferation and differentiation58. $\mathrm{ENaC}$ has been functionally detected in both club cells and AT2 cells59. Whether ENaC is a member of the fibrinolytic niche for lung stem cell-mediated regeneration is unknown. We recently reported that overexpression of the Scnnld, a pseudogene in mice, significantly improves the development of organoids in 3D cultures of primary mouse AT2 cells 60 . Together with abnormal ENaC activity in Plau ${ }^{-/}$and Serpine $1^{T g}$ AT2 cells, we conclude that the ENaC signal may be an essential regulator for the fate of AT2 cells in normal and injured lungs.

In summary, our study uncovers a novel role of the fibrinolytic niche in alveolarization via the uPA/A6/CD44 and the $\mathrm{uPA} / \mathrm{ENaC}$ signaling pathways. This study provides new evidence for the possible prognostic relevance of the fibrinolytic niche for ARDS patients. Targeting the abnormality of the fibrinolytic niche could be a promising pharmaceutic strategy to accelerate reparative processes of injured alveolar epithelium in clinical disorders such as ARDS.

\section{METHODS}

Methods, including statements of data availability and any associated accession codes and references, are available in the online version of this paper.

\section{ACKNOWLEDGMENTS}

This work was supported by NIH grant R01 HL134828 and Donor West (California). 


\section{AUTHOR CONTRIBUTIONS}

Conceptualization: H.L.J. and M.A.M; investigation: G.A., R.Z.Z, J.C., M.Z., S.K., X. F., B. Z., J.L., D. J. M. I., K.G.J.; formal analysis: G.A, H.L.J, D. J., K.G.J.; writing: G.A., H.L.J., M.A.M.; supervision: H.L.J., M.A.M.; funding: H.L.J., M.A.M.

\section{COMPETING FINANCIAL INTERESTS}

Dr. Matthay has NHLBI and Department of Defense support for his research. In addition, Dr. Matthay has research grant support from Bayer Pharmaceuticals and Genentech Roche although there is no financial conflict with the studies in these studies. The other authors declare no competing financial interest. 


\section{Figure Legends}

Figure 1. Quantification of AT2 cells in influenza-infected mouse lungs and ARDS lungs. Lung sections from control and influenza PR8 H1N1 infected mice were fixed and stained with anti-pdpn (AT1, red) and anti-sftpc (AT2, green) antibodies. Z-stacked confocal images of lung sections were prepared based on the severity of lung injury. (a) Images for wt mice 5 days post infection. $n=10$ sections from 3 different mice per group. (b) Images for Plau $^{-/}$lungs. $\mathrm{n}=10$ sections from 7 different mice per group. (c) AT2 cells in normal and injured mouse lung sections. Mod, moderate. Sev, severe. $n=18$ images from 3 different samples per group. (d-f) CD44 ${ }^{+}$AT2 cells isolated from ARDS lungs. (d) Yield of AT2 cells from Plau ${ }^{-/-}$and wt control mice. (n = 15 mice/genotype). Human AT2 cells isolated from 6 donors with FACS were slightly cultured for 24 - 48 h to improve viability, and then ran FACS for sorting CD44+ population was sorted by FACS for healthy control (e) and ARDS patients (f). (g) Average CD44+ cells (\%). The data were analysed with one-way ANOVA followed by the Tukey post hoc test. $\mathrm{n}=12$ samples. $* \mathrm{P}<0.05$ vs healthy controls. Data in $\mathrm{c}$ and $\mathrm{g}$ are mean \pm sem and analyzed with one-way ANOVA. ${ }^{* *} \mathrm{P} \leq 0.01$ and $* * * \mathrm{P} \leq 0.001$ vs wt controls at the same severity. $\# \mathrm{P} \leq 0.05$ and $\# \# \mathrm{P} \leq 0.01$ compared with controls for wt. \& $\mathrm{P} \leq 0.05$ and $\& \& \& \mathrm{P} \leq 0.001$ vs controls for Plau ${ }^{-/-}$group.

Figure 2. UPA is required for AT2 cells to develop spheroids in three-dimensional cultures. Colony formation observed and analyzed from day 4 to day 12 post seeding. (a) Representative phase-contrast images of colony per well for both wt and Plaü-/- AT2 cells. $\mathrm{n}=16$ wells per set of experiments and repeated with 6 pairs of mice. (b-c) Colony number (b) and colony forming efficiency (CFE, c) on day 8 of the cultures. $n=46$. (d) Colony number as a function of the size (average diameter in $\mu \mathrm{m}$ ). (e) Total organoid surface area per well. $\mathrm{n}=$ 46. Data in b, c, d, e, and g are mean \pm sem and analyzed with the Student's t-test. * indicates $\mathrm{P} \leq 0.05$ and $* * \mathrm{P}$ $\leq 0.01$ compared with wt controls. (f-g) Representative images of organoid sections stained with the H \& E procedure for wt (f) and Plau $^{-/}$group (g). Scale bar, $50 \mu \mathrm{m}$.

Figure 3. Bioelectric features of wt and Plau $^{-/-}$AT2 monolayer cells. (a) Representative short-circuit current (Isc) in the presence and absence of bath $\mathrm{Na}^{+}$ions. The bath solution was replaced with $\mathrm{Na}^{+}$free medium as indicated by arrows. (b) Summarized Isc level. $n=15$. (c) Isc traces in the presence of accumulating amiloride added to the apical compartment. (d) Amiloride sensitivity of transepithelial Isc activity in AT2 monolayers. 
Dotted and dashed lines are generated by fitting raw data points with the Hill equation to compute $\mathrm{IC}_{50}$ value for amiloride. (e) Transepithelial resistance of AT2 monolayers measured with a chopstick meter. $\mathrm{n}=15$ monolayers from 3 different cell preparations. Data in $b$, d, and c are represented as mean \pm sem and analyzed with the Student's t-test. $* * *$ indicates $\mathrm{P} \leq 0.001$ vs basal Isc levels (b) or wt controls (e), \&\& $\mathrm{P} \leq 0.01$ vs wt controls (b).

Figure 4. Proliferation and differentiation of AT2 cells in 3D organoid and polarized monolayer cultures.

Cells were collected from organoids and monolayers on day 7 of the cultures at the air-liquid mode. (a-b) Stacked confocal images of wt (a) and Plau ${ }^{-/-}$organoids. AT1 and AT2 cells were identified as pdpn-positive (red) and sftpc-positive (green) cells, respectively. Stacked 3D image for each organoid was constructed, and cells were counted through the whole organoid. Scale bar, $100 \mu \mathrm{m}$. (c) Comparison of cell number for AT1, AT2 cells, and the sum of AT1 and AT2 cells (both). $\mathrm{n}=16$ organoids per group from three separate experiments. $* \mathrm{P}<0.05$ and $* * \mathrm{P}<0.01$ compared with wt. (d-e) Confocal images polarized AT2 monolayers. AT1 and AT2 biomarkers are pdpn and sftpc, respectively. Scale bar, $100 \mu \mathrm{m}$. (f) FACS analysis of cell types. $\mathrm{n}=19$ transwells per group from three separate experiments. ${ }^{* *} \mathrm{P}<0.01$ compared with wt. Data in $\mathrm{c}$ and $\mathrm{f}$ are means \pm sem. The data were analyzed with the Student's t-test.

Figure 5. Detection of proliferative AT2 cells in organoids and polarized monolayers. A Click-iT EdU assay kit was used to identify AT2 cells with active DNA synthesis on day 7 of the cultures. (a) Images of wt (upper panel) and Plau $^{-/}$(lower panel) monolayers for DAPI (left), EdU (middle), and merged (right). Original magnification is $400 \times$. Scale bar, $50 \mu \mathrm{m}$. (b) EdU ${ }^{+}$cells (\%) in wt and Plau ${ }^{-/-}$monolayers. $\mathrm{n}=16$ per group from 6 separate preparations. (c) Stacked organoid images of DAPI for nuclei (left), EdU (middle), and merged (right). Original magnification is $400 \times$. Scale bar, $50 \mu \mathrm{m}$. (d) EdU ${ }^{+}$cells $(\%)$ in wt and Plau ${ }^{-/-}$organoids. $\mathrm{n}=25$ for each group from 6 separate preparations. Data in $\mathrm{b}$ and $\mathrm{d}$ are means \pm sem. The data were analyzed with the Student's t-test. $* * * \mathrm{P} \leq 0.001$ vs wt controls.

Figure 6. Effects of the A6 peptide and CD44 receptor on the formation of organoids and AT2 lineage. (a) Representative DIC images of organoids showing the effects of A6 peptides. AT2 cells isolated from Plau $^{-/-}$mice were treated with either A6 derived from uPA or scrambled A6 peptides (sA6) in 3D organoid cultures with wt 
cultures as controls. (b) Organoid counts for each group. $\mathrm{n}=16$ transwells/ group from 6 independent experiments. (c-d) FlowJo analyzed FACS results. Wt AT2 cells were treated with blocking antibody against CD44 receptor (c), and Plau ${ }^{-/}$cells were incubated with A6 peptide (d). Pdpn and EpCAM are biomarkers for AT1 and AT2 cells, respectively. (e-f) Cell sorting results for AT1 (d) and AT2 cells (f). n = 12 transwells for each group from 6 independent experiments. Data in $b$, e, and $f$ are means \pm sem, and analysed with one-way ANOVA followed by Tukey post hoc test. NS, not significant, $* \mathrm{P} \leq 0.05$, and $* * * \mathrm{P} \leq 0.001$ compared with those groups as the horizontal lines indicated.

Figure 7. Roles of CD44 expression in AT2-mediated alveologenesis in vitro. Potentially impaired CD44 receptors at the plasma membrane of AT2 cells were restored by culturing on collagen IV coated plates cultured for $24-36 \mathrm{~h}$ at $37^{\circ} \mathrm{C}$. Then cells were detached and sorted as $\mathrm{EpCAM}^{+} \mathrm{CD} 44^{+}$and $\mathrm{EpCAM}^{+} \mathrm{CD} 44^{-}$ subpopulations. (a) FACS sorted $\mathrm{EpCAM}^{+} \mathrm{CD}_{4} 4^{+} \mathrm{AT} 2$ cells for wt (left) and Plau ${ }^{-/}$(right) groups. Comparison of the number of EpCAM ${ }^{+} \mathrm{CD}_{4} 4^{+} \mathrm{AT} 2$ cells between wt and $\mathrm{Plau}^{-/-}$mice. $\mathrm{n}=7$ mice / genotype. (c) DIC images of organoids formed by sorted CD44+ (upper panel) and CD44- (lower panel) AT2 cells on day 7. (d-e) Number of organoids per transwell for CD44+ $(d)$ and CD44- (e) AT2 cells. $n=18$ for each group from four independent experiments. (f) FACS analysis of AT1 $\left(\mathrm{PdPn}^{+} \mathrm{ICAM}^{+}\right)$and AT2 (EpCAM $\left.{ }^{+}\right)$cells. (g-h) Statistical comparison of AT1 and AT2 cells in organoids grown from $\mathrm{CD}_{4}^{+}(\mathrm{g})$ and $\mathrm{CD}_{4}^{-}(\mathrm{h})$ subpopulations. $\mathrm{n}=12$ transwells per group from three independent experiments. Data in b, d, e, g, and h are means \pm sem and analysed with the Student's t-test in b, pair signed rank test in d-e and one-way ANOVA followed by Tukey post hoc analysis in $\mathrm{g}-\mathrm{h}$. NS, not significant, $* \mathrm{P} \leq 0.05$, and $* * * \mathrm{P} \leq 0.001$ compared with wt controls.

Figure 8. Effects of PAI-1 overexpression on the regenerative and channel function of AT2 cells. AT2 cells were isolated from wt and PAI-1 $1^{T g}$ mice overexpressing mutated gain-of-function human PAI-1 gene. (a) Different yields of AT2 cells between wt and PAI- $1^{T g}$ mice. $\mathrm{n}=11$ pairs of mice. AT2 cells were harvested in parallel from one pair of wt and PAI-1 $1^{T g}$ mice per experiment. (b) Comparison of the yield of FACS-sorted CD44 ${ }^{+}$AT2 cells between wt and PAI-1 $1^{T g}$ mice. (c) Difference in the number of CD44 ${ }^{+}$AT2 cells in vivo between wt and $P A I-1^{T g}$ mice. $\mathrm{n}=9$ pairs of mice. (d) DIC images of AT2 organoids for wt (left) and $P A I-1^{T g}$ mice. Scale bar, $100 \mu \mathrm{m}$. (e-f) Organoid number (e) and total surface area (f) of organoids per transwell. $\mathrm{n}=15$ transwells per 
group. (g) FACS analysis of AT1 (ICAM $\left.{ }^{+}\right)$and AT2 (EpCAM $\left.{ }^{+}\right)$cells. (h) Cell count for AT1 and AT2 cells. n $=3$ pairs of mice. (i) Transepithelial resistance $\left(\mathrm{R}_{\mathrm{T}}\right)$ of AT2 monolayers measured with a chopstick meter. $\mathrm{n}=$ 16 monolayers per group. (j) Representative short-circuit current (Isc) traces in response to accumulating amiloride doses. (k) Amiloride sensitivity. Raw data from (j) were fitted with the Hill equation to compute $\mathrm{IC}_{50}$ value. $\mathrm{n}=12$. Data in $\mathrm{a}, \mathrm{c}, \mathrm{e}, \mathrm{f}, \mathrm{h}, \mathrm{i}$, and $\mathrm{k}$ are mean \pm s.e.m. and analysed with one-way ANOVA followed by the Tukey post hoc test in (i) and the Student's t-test in others. NS, not significant, $* \mathrm{P} \leq 0.05$, and ** $\mathrm{P} \leq 0.01$ compared with wt controls. 


\section{References}

1. Barkauskas, C.E. et al. Type 2 alveolar cells are stem cells in adult lung. J Clin Invest 123, 3025-3036 (2013).

2. Beers, M.F.M., E.E. The three R's of lung health and disease: repair, remodeling, and regeneration. J. Clin. Invest 121, 2065-2073 (2011).

3. Wansleeben, C., Barkauskas, C.E., Rock, J.R. \& Hogan, B.L. Stem cells of the adult lung: their development and role in homeostasis, regeneration, and disease. Wiley Interdiscip Rev Dev Biol 2, 131-148 (2013).

4. Chen, J. Origin and regulation of a lung repair kit. Nat Cell Biol 19, 885-886 (2017).

5. Liu, Y., Kumar, V.S., Zhang, W., Rehman, J. \& Malik, A.B. Activation of type II cells into regenerative stem cell antigen-1(+) cells during alveolar repair. Am J Respir Cell Mol Biol 53, 113-124 (2015).

6. Hofer, C.C., Woods, P.S. \& Davis, I.C. Infection of mice with influenza A/WSN/33 (H1N1) virus alters alveolar type Il cell phenotype. Am J Physiol Lung Cell Mol Physiol 308, L628-638 (2015).

7. Kasper, M. \& Barth, K. Potential contribution of alveolar epithelial type I cells to pulmonary fibrosis. Biosci Rep 37, 1-18 (2017).

8. Iosifidis, T. et al. Airway epithelial repair in health and disease: Orchestrator or simply a player? Respirology 21, 438-448 (2016).

9. Heissig, B. et al. Role of mesenchymal stem cell-derived fibrinolytic factor in tissue regeneration and cancer progression. Cell Mol Life Sci 72, 4759-4770 (2015).

10. Smith, H.W. \& Marshall, C.J. Regulation of cell signalling by uPAR. Nat Rev Mol Cell Biol 11, 23-36 (2010).

11. Vallabhaneni, K.C. et al. Urokinase receptor mediates mobilization, migration, and differentiation of mesenchymal stem cells. Cardiovasc Res 90, 113-121 (2011).

12. Neuss, S., Schneider, R.K., Tietze, L., Knuchel, R. \& Jahnen-Dechent, W. Secretion of fibrinolytic enzymes facilitates human mesenchymal stem cell invasion into fibrin clots. Cells Tissues Organs 191, 36-46 (2010).

13. Novak, M.L. et al. Macrophage-specific expression of urokinase-type plasminogen activator promotes skeletal muscle regeneration. J Immunol 187, 1448-1457 (2011).

14. Popa, N.L., Wergedal, J.E., Lau, K.H., Mohan, S. \& Rundle, C.H. Urokinase plasminogen activator gene deficiency inhibits fracture cartilage remodeling. J Bone Miner Metab 32, 124-135 (2014).

15. Nassar, T. et al. Binding of urokinase to low density lipoprotein-related receptor (LRP) regulates vascular smooth muscle cell contraction. J Biol Chem 25, 40499-40504 (2002).

16. Armstead, W.M., Cines, D.B. \& Higazi, A.A. Plasminogen activators contribute to impairment of hypercapnic and hypotensive cerebrovasodilation after cerebral hypoxia/ischemia in the newborn pig. Stroke 36, 2265-2269 (2005).

17. Armstead, W.M., Christine, A.J., Higazi, A.A. \& Cines, D.B. Urokinase plasminogen activator impairs SNP and PGE2 cerebrovasodilation after brain injury through activation of LRP and ERK MAPK. J Neurotrauma 25, 1375-1381 (2008).

18. Schuliga, M., Westall, G., Xia, Y. \& Stewart, A.G. The plasminogen activation system: new targets in lung inflammation and remodeling. Curr Opin Pharmacol 13, 386-393 (2013).

19. Chen, Z. et al. Regulation of epithelial sodium channels in urokinase plasminogen activator deficiency. Am J Physiol Lung Cell Mol Physiol 307, L609-617 (2014).

20. Chapman, H.A. Epithelial-mesenchymal interactions in pulmonary fibrosis. Annu Rev Physiol 73, 413-435 (2011).

21. Teriete, P. et al. Structure of the regulatory hyaluronan binding domain in the inflammatory leukocyte homing receptor CD44. Mol Cell 13, 483-496 (2004).

22. Baggio, C., Barile, E., Di Sorbo, G., Kipps, T.J. \& Pellecchia, M. The cell surface receptor CD44: NMR-based characterization of putative ligands. Chem Med Chem 11, 1097-1106 (2016).

23. Chen, Q. et al. CD44(high) alveolar type II cells show stem cell properties during steady-state alveolar homeostasis. Am J Physiol Lung Cell Mol Physiol 313, L41-L51 (2017).

24. Bhandary, Y.P. et al. Plasminogen activator inhibitor-1 in cigarette smoke exposure and influenza A virus infectioninduced lung injury. PLoS One 10, e0123187 (2015).

25. Hou, Y. et al. Upregulation of the WNK4 Signaling Pathway Inhibits Epithelial Sodium Channels of Mouse Tracheal Epithelial Cells After Influenza A Infection. Frontiers in pharmacology 10, 12-12 (2019). 
26. Matute-Bello, G. et al. An official American Thoracic Society workshop report: features and measurements of experimental acute lung injury in animals. Am J Respir Cell Mol Biol 44, 725-738 (2011).

27. Chen, Z. et al. Regulation of epithelial sodium channels in urokinase plasminogen activator deficiency. American journal of physiology. Lung cellular and molecular physiology 307, L609-L617 (2014).

28. Groeneveld, A.B., Kindt, I., Raijmakers, P.G., Hack, C.E. \& Thijs, L.G. Systemic coagulation and fibrinolysis in patients with or at risk for the adult respiratory distress syndrome. Thrombosis and haemostasis 78, 1444-1449 (1997).

29. Liu, C. et al. Meta-Analysis of Preclinical Studies of Fibrinolytic Therapy for Acute Lung Injury. Frontiers in immunology 9, 1898-1898 (2018).

30. Prabhakaran, P. et al. Elevated levels of plasminogen activator inhibitor-1 in pulmonary edema fluid are associated with mortality in acute lung injury. American journal of physiology. Lung cellular and molecular physiology 285, L20-L28 (2003).

31. Sapru, A., Curley, M.A.Q., Brady, S., Matthay, M.A. \& Flori, H. Elevated PAI-1 is associated with poor clinical outcomes in pediatric patients with acute lung injury. Intensive care medicine 36, 157-163 (2010).

32. Ware, L.B. et al. Pathogenetic and prognostic significance of altered coagulation and fibrinolysis in acute lung injury/acute respiratory distress syndrome. Critical care medicine 35, 1821-1828 (2007).

33. El Solh, A.A. et al. Alveolar plasminogen activator inhibitor-1 predicts ARDS in aspiration pneumonitis. Intensive care medicine 32, 110-115 (2006).

34. Fahim, A.T., Wang, H., Feng, J. \& Ginsburg, D. Transgenic overexpression of a stable Plasminogen Activator Inhibitor-1 variant. Thrombosis research 123, 785-792 (2009).

35. Erickson, L.A. et al. Development of venous occlusions in mice transgenic for the plasminogen activator inhibitor1 gene. Nature 346, 74-76 (1990).

36. Bhandary, Y.P. et al. Regulation of alveolar epithelial cell apoptosis and pulmonary fibrosis by coordinate expression of components of the fibrinolytic system. Am J Physiol Lung Cell Mol Physiol 302, L463-473 (2012).

37. Tucker, T. \& Idell, S. Plasminogen-plasmin system in the pathogenesis and treatment of lung and pleural injury. Semin Thromb Hemost 39, 373-381 (2013).

38. Ozolina, A. et al. Activation of coagulation and fibrinolysis in acute respiratory distress syndrome: A prospective pilot study. Front Med (Lausanne) 3, 64 (2016).

39. Ware, L.B. et al. Pathogenetic and prognostic significance of altered coagulation and fibrinolysis in acute lung injury/acute respiratory distress syndrome. Crit Care Med 35, 1821-1828 (2007).

40. Flick, M.J. \& Bugge, T.H. Plasminogen-receptor KT : plasminogen activation and beyond. J Thromb Haemost 15, 150-154 (2017).

41. Lund, L.R. et al. Plasminogen activation independent of UPA and tPA maintains wound healing in gene-deficient mice. EMBO J 25, 2686-2697 (2006).

42. Koh, T.J., Bryer, S.C., Pucci, A.M. \& Sisson, T.H. Mice deficient in plasminogen activator inhibitor-1 have improved skeletal muscle regeneration. Am J Physiol Cell Physiol 289, C217-223 (2005).

43. Gueler, F. et al. Renal urokinase-type plasminogen activator (UPA) receptor but not uPA deficiency strongly attenuates ischemia reperfusion injury and acute kidney allograft rejection. J Immunol 181, 1179-1189 (2008).

44. Zhang, G. \& Eddy, A.A. Urokinase and its receptors in chronic kidney disease. Front Biosci 13, $5462-5478$ (2008).

45. Liu, K., Fan, J. \& Wu, J. Sushi repeat-containing protein X-linked 2 promotes angiogenesis through the urokinasetype plasminogen activator receptor dependent integrin alphavbeta3/focal adhesion kinase pathways. Drug Discov Ther 11, 212-217 (2017).

46. Stepanova, V. et al. Urokinase-type plasminogen activator (UPA) promotes angiogenesis by attenuating prolinerich homeodomain protein (PRH) transcription factor activity and de-repressing vascular endothelial growth factor (VEGF) receptor expression. J Biol Chem 291, 15029-15045 (2016).

47. Oh, C.W., Hoover-Plow, J. \& Plow, E.F. The role of plasminogen in angiogenesis in vivo. J Thromb Haemost 1, 16831687 (2003).

48. Cooper, F. et al. Enhancement of cutaneous wound healing by Dsg2 augmentation of uPAR secretion. $J$ Invest Dermatol 138, 2470-2479 (2018).

49. Balsara, R.D., Castellino, F.J. \& Ploplis, V.A. A novel function of plasminogen activator inhibitor-1 in modulation of the AKT pathway in wild-type and plasminogen activator inhibitor-1-deficient endothelial cells. J Biol Chem 281, 22527-22536 (2006). 
50. Ploplis, V.A. et al. Enhanced in vitro proliferation of aortic endothelial cells from plasminogen activator inhibitor1-deficient mice. J Biol Chem 279, 6143-6151 (2004).

51. Ji, H.L. et al. Proteolytic regulation of epithelial sodium channels by urokinase plasminogen activator: cutting edge and cleavage sites. J Biol Chem 290, 5241-5255 (2015).

52. Svenningsen, P., Hinrichs, G.R., Zachar, R., Ydegaard, R. \& Jensen, B.L. Physiology and pathophysiology of the plasminogen system in the kidney. Pflugers Archiv : European journal of physiology 469, 1415-1423 (2017).

53. Zhao, R. et al. Plasmin improves oedematous blood-gas barrier by cleaving epithelial sodium channels. $\mathrm{Br} J$ Pharmacol (2020).

54. Jiang, D. et al. Regulation of lung injury and repair by Toll-like receptors and hyaluronan. Nat Med 11, 1173-1179 (2005).

55. Finlayson, M. Modulation of CD44 activity by A6-peptide. Front Immunol 6, 135 (2015).

56. Piotrowicz, R.S. et al. A6 peptide activates CD44 adhesive activity, induces FAK and MEK phosphorylation, and inhibits the migration and metastasis of CD44-expressing cells. Mol Cancer Ther 10, 2072-2082 (2011).

57. Liang, J. et al. CD44 is a negative regulator of acute pulmonary inflammation and lipopolysaccharide-TLR signaling in mouse macrophages. J Immunol 178, 2469-2475 (2007).

58. Petrik, D. et al. Epithelial sodium channel regulates adult neural stem cell proliferation in a flow-dependent manner. Cell Stem Cell 22, 865-878 e868 (2018).

59. Liu, Y., Jiang, B.J., Zhao, R.Z. \& Ji, H.L. Epithelial sodium channels in pulmonary epithelial progenitor and stem cells. Int J Biol Sci 12, 1150-1154 (2016).

60. Zhao, R. et al. Proliferative regulation of alveolar epithelial type 2 progenitor cells by human Scnn1d gene. Theranostics 9, 8155-8170 (2019). 
Figure 1

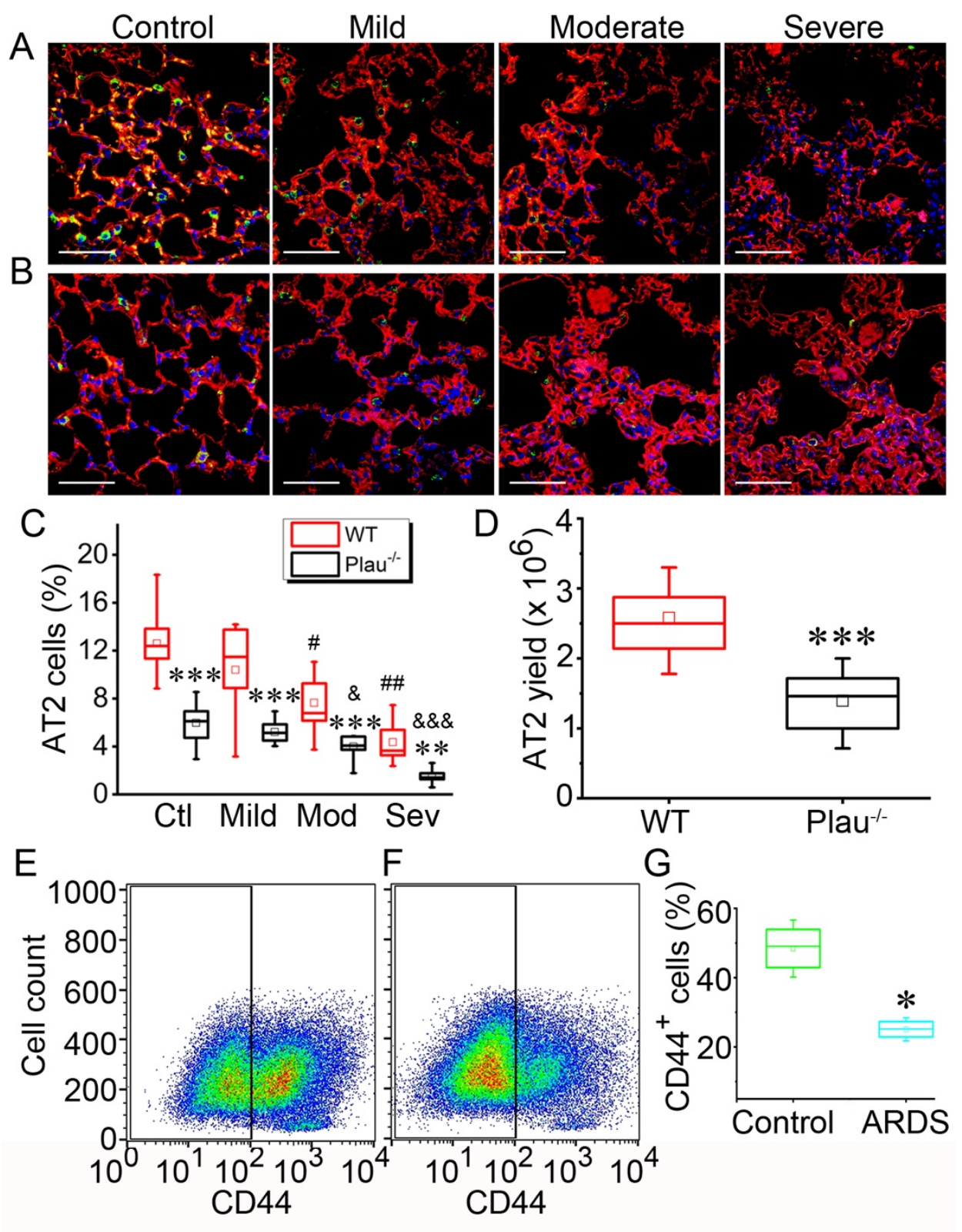


Figure 2

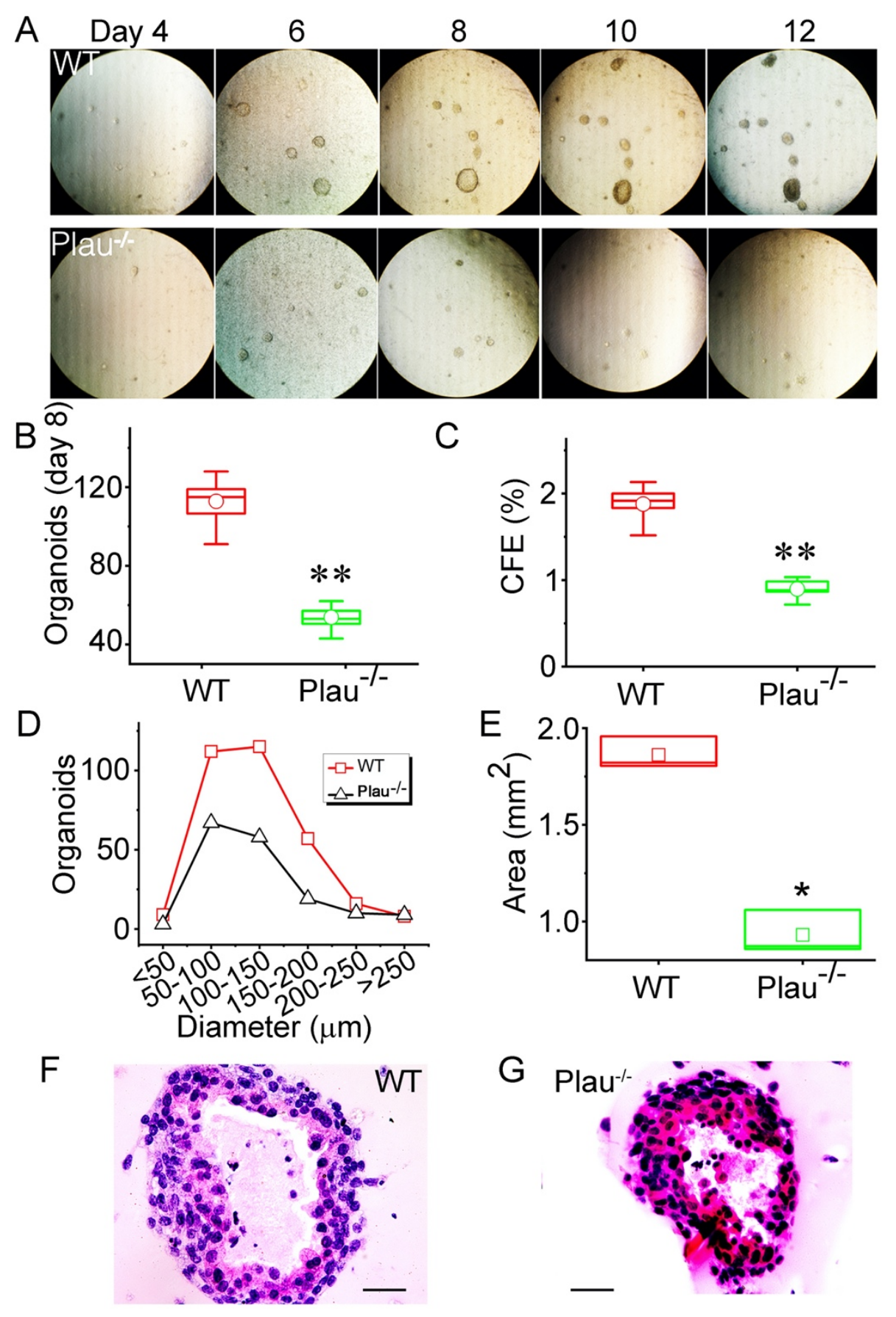


Figure 3
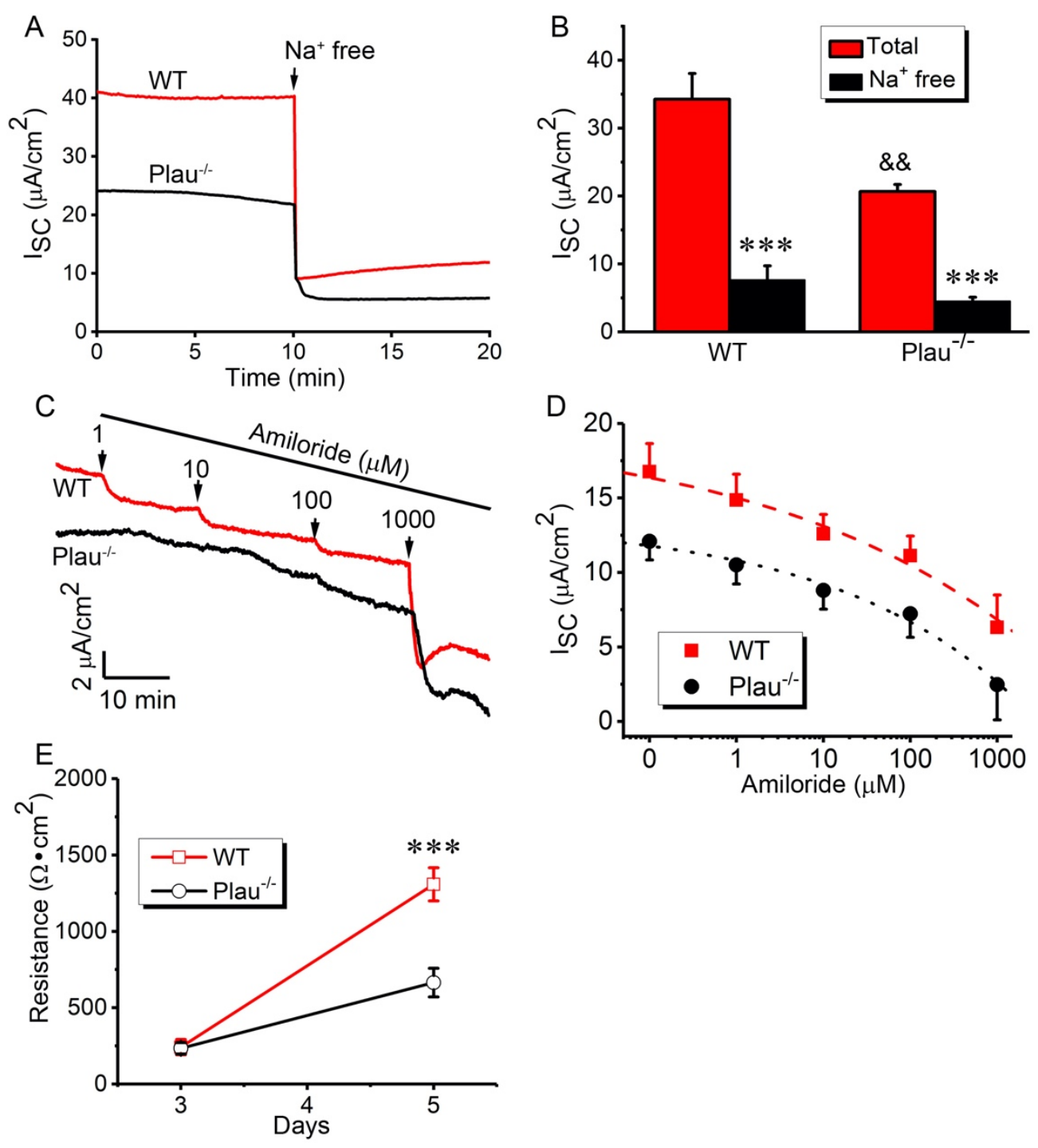
Figure 4
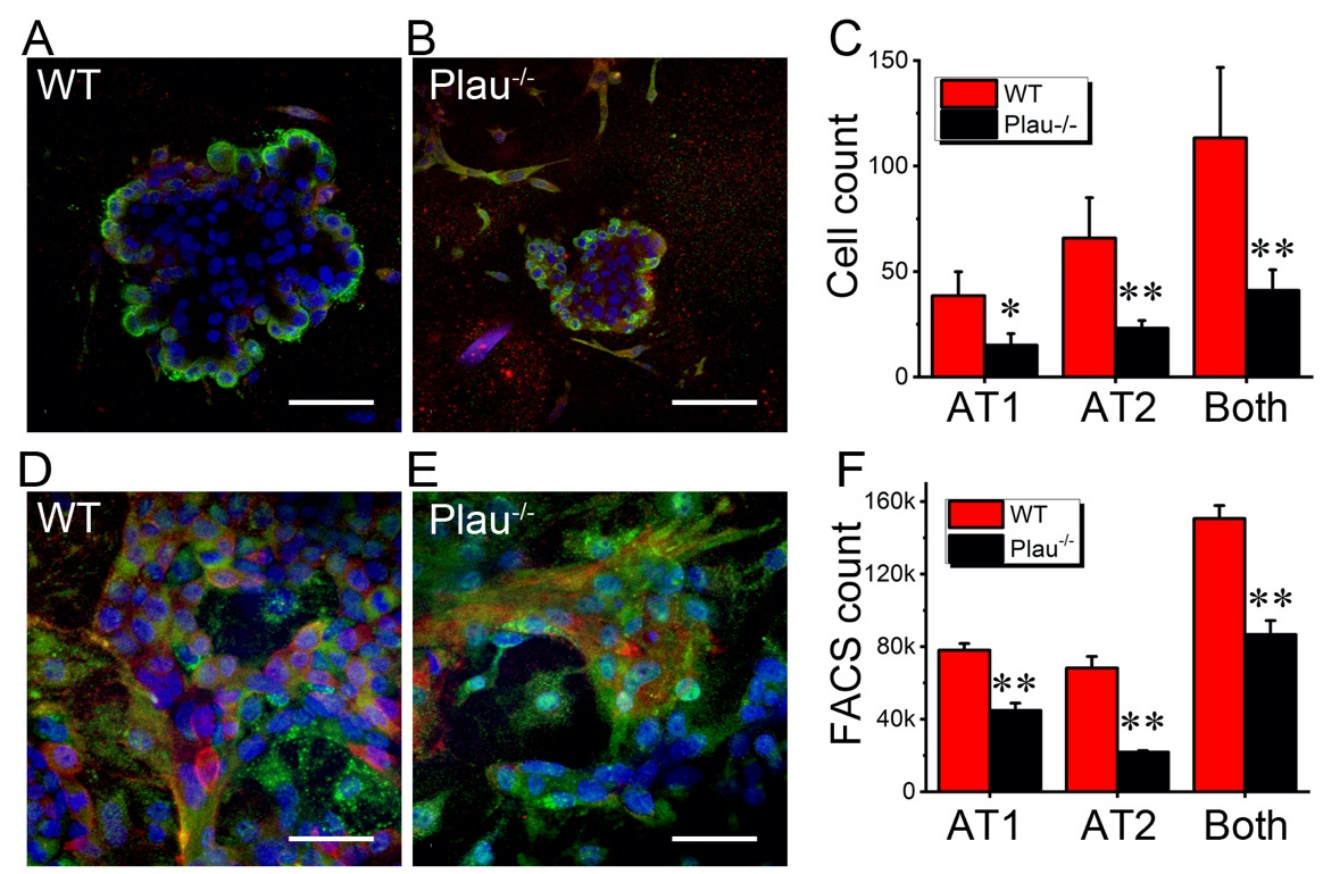
Figure 5
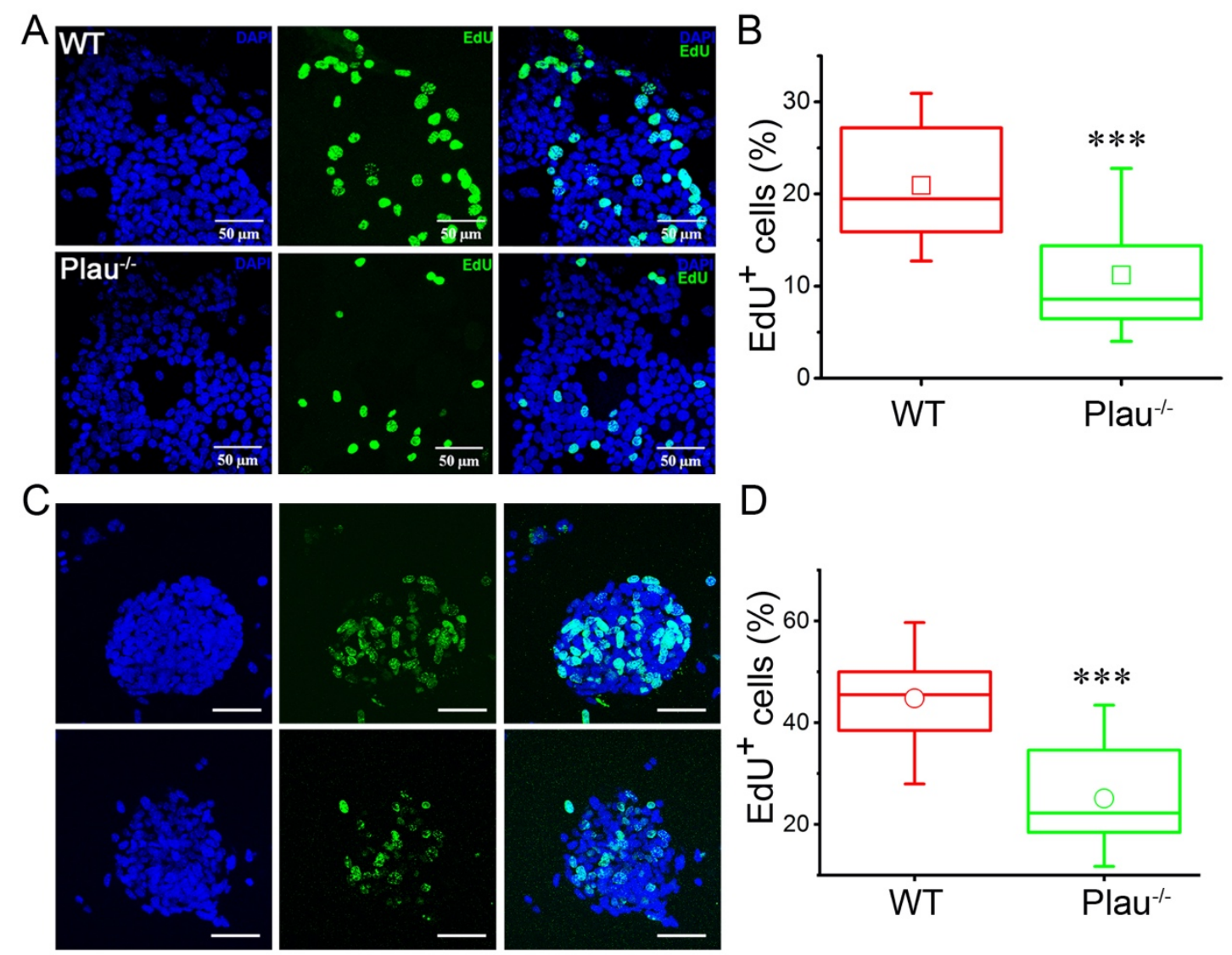

D

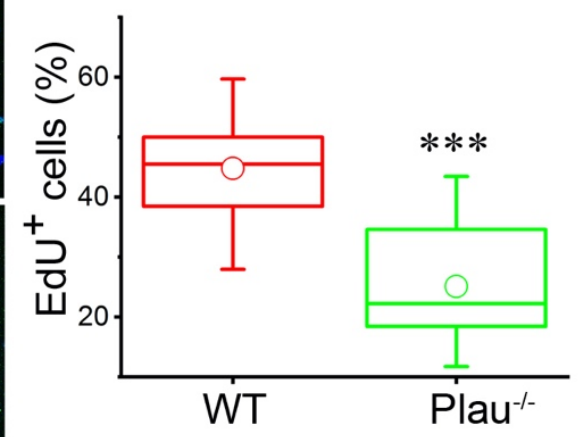


Figure 6
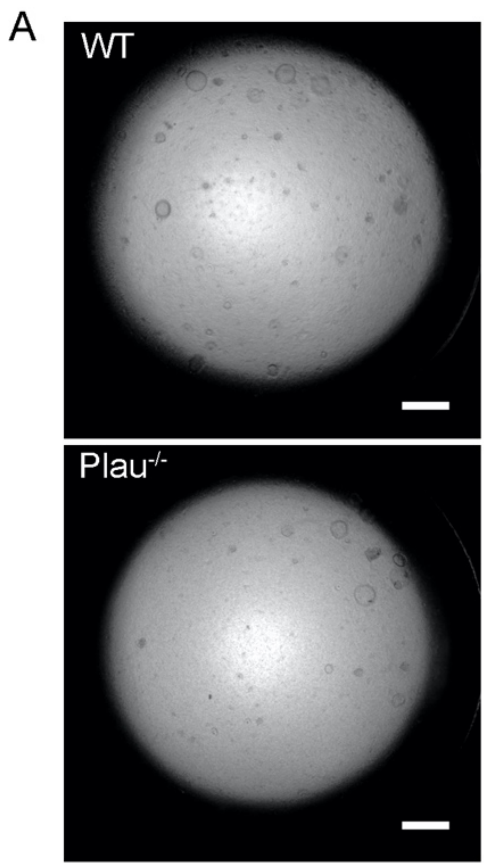

C

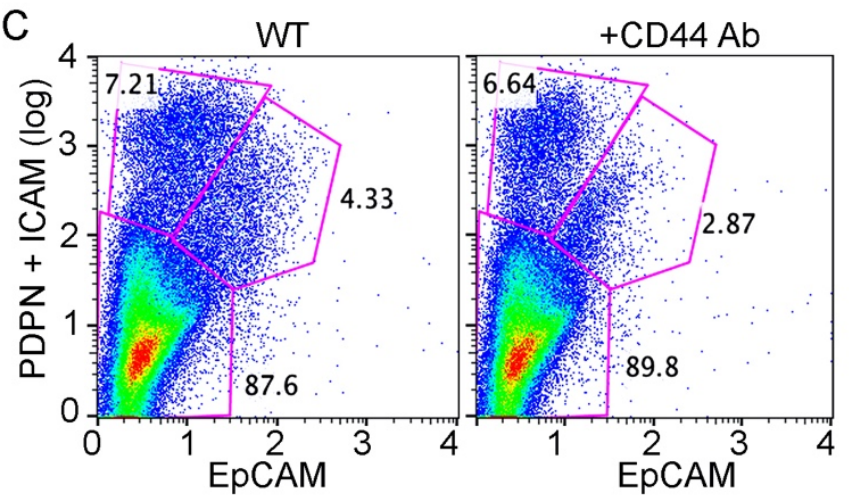

B

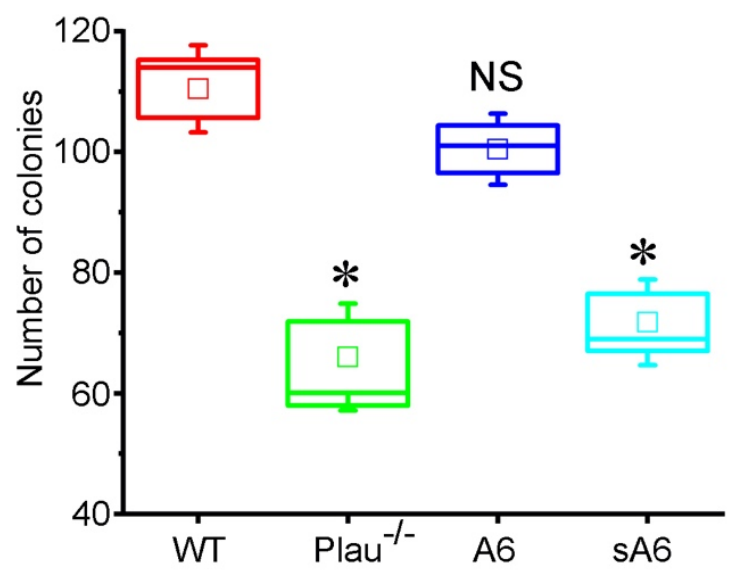

E

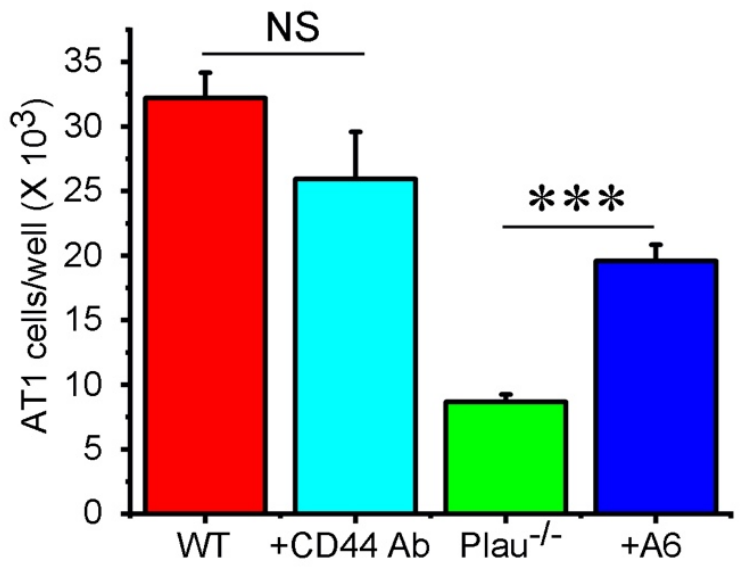

D

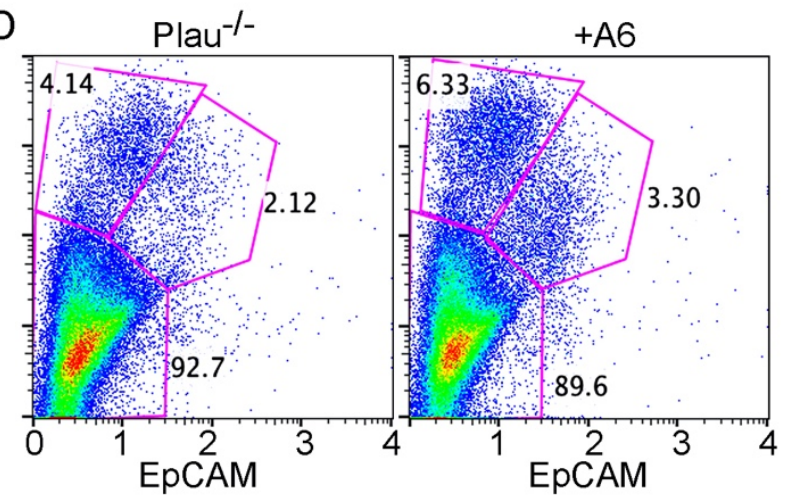

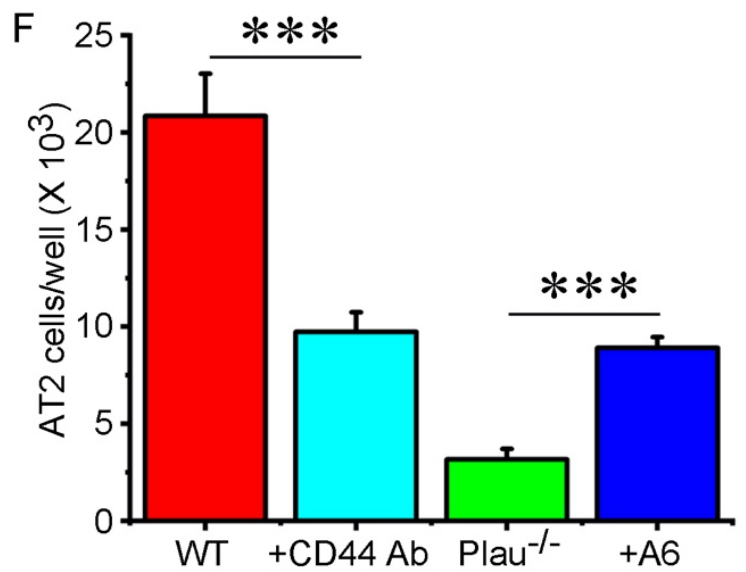


Figure 7
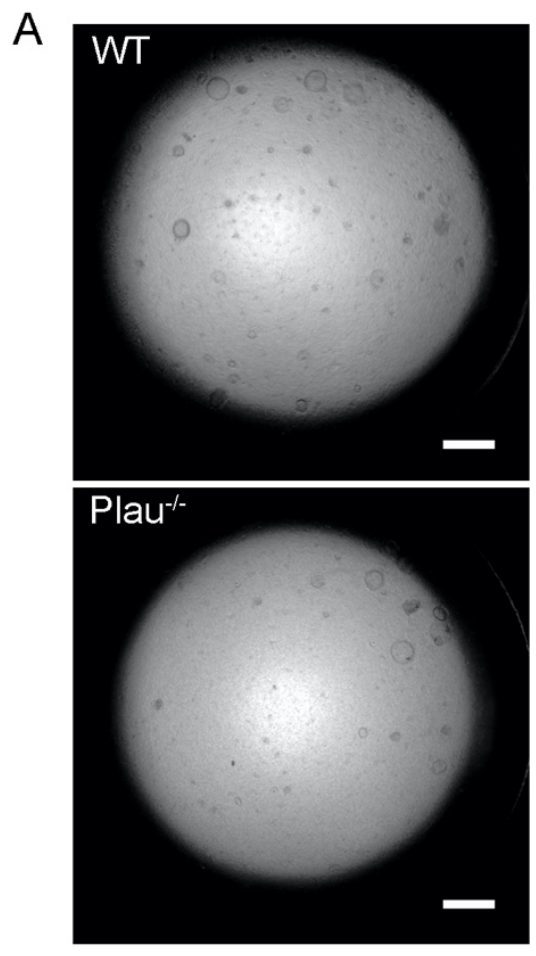

$\mathrm{C}$

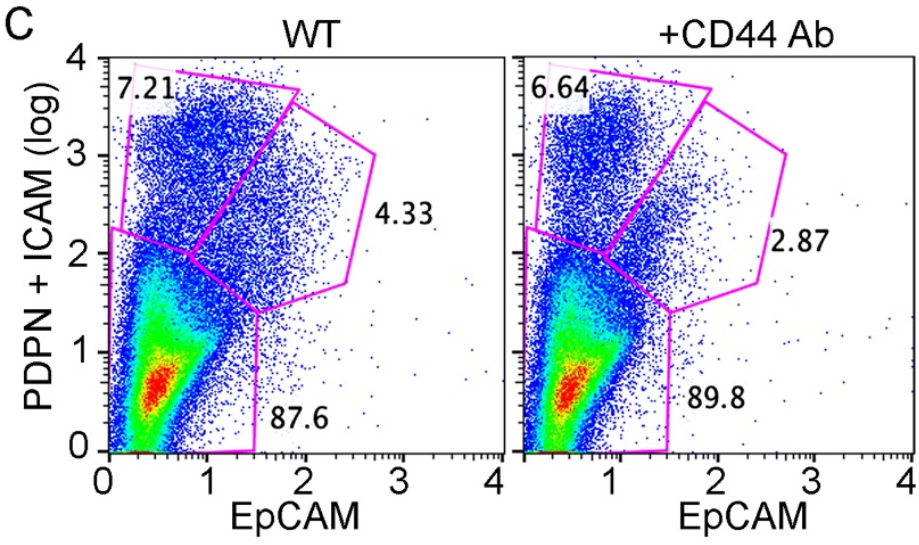

B

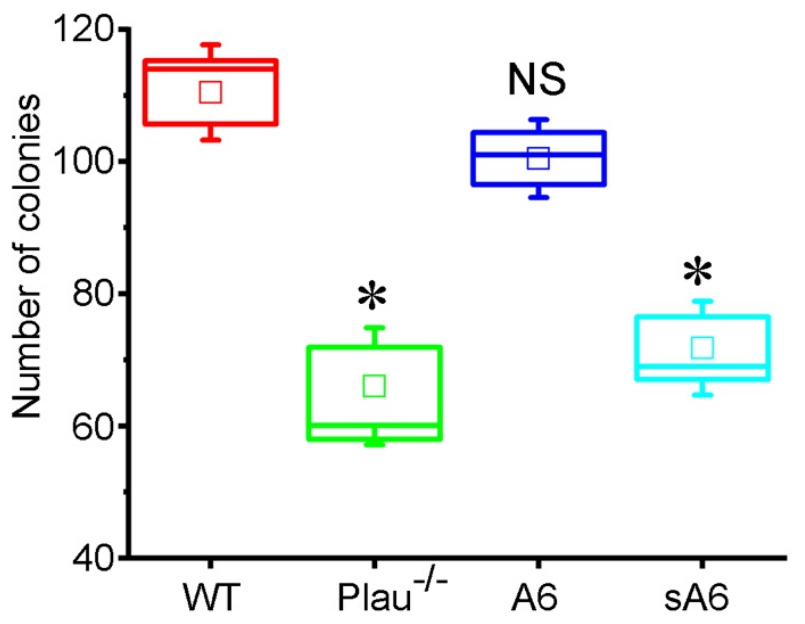

E

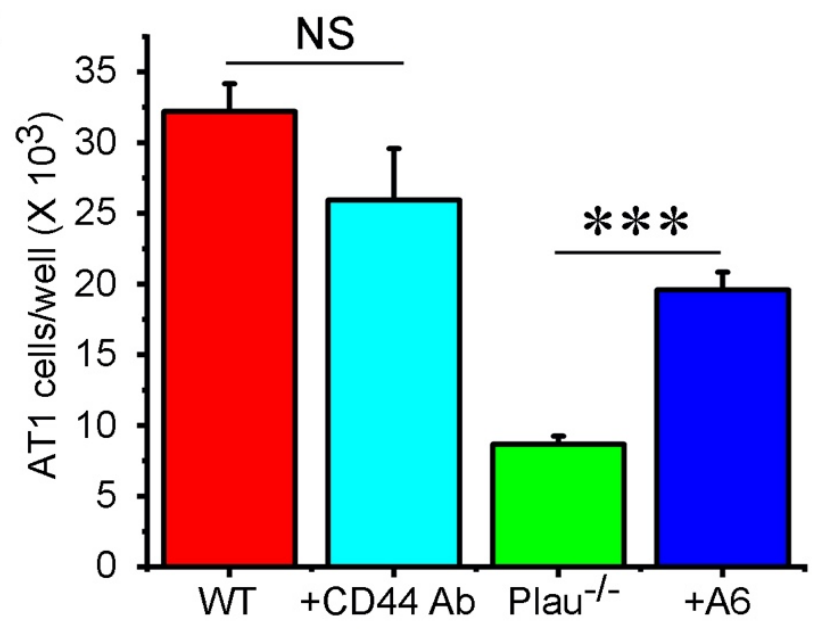

D

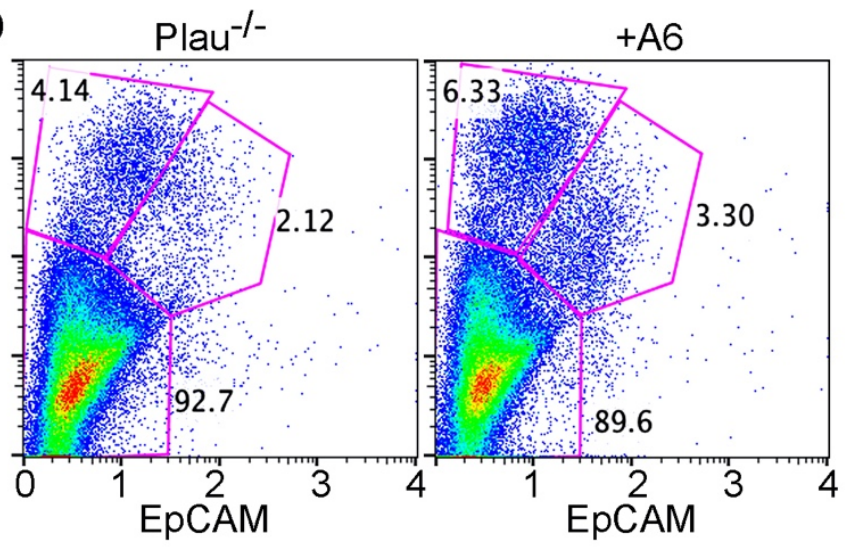

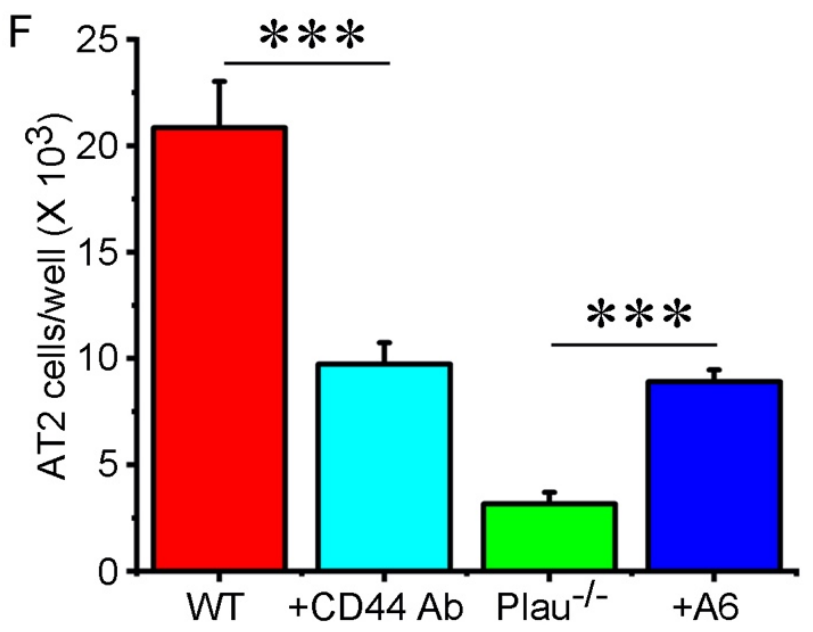


Figure 8

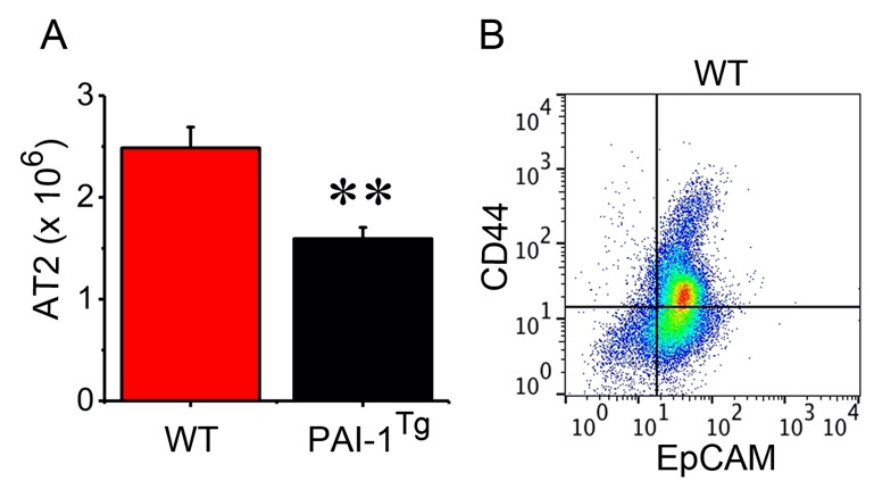

D
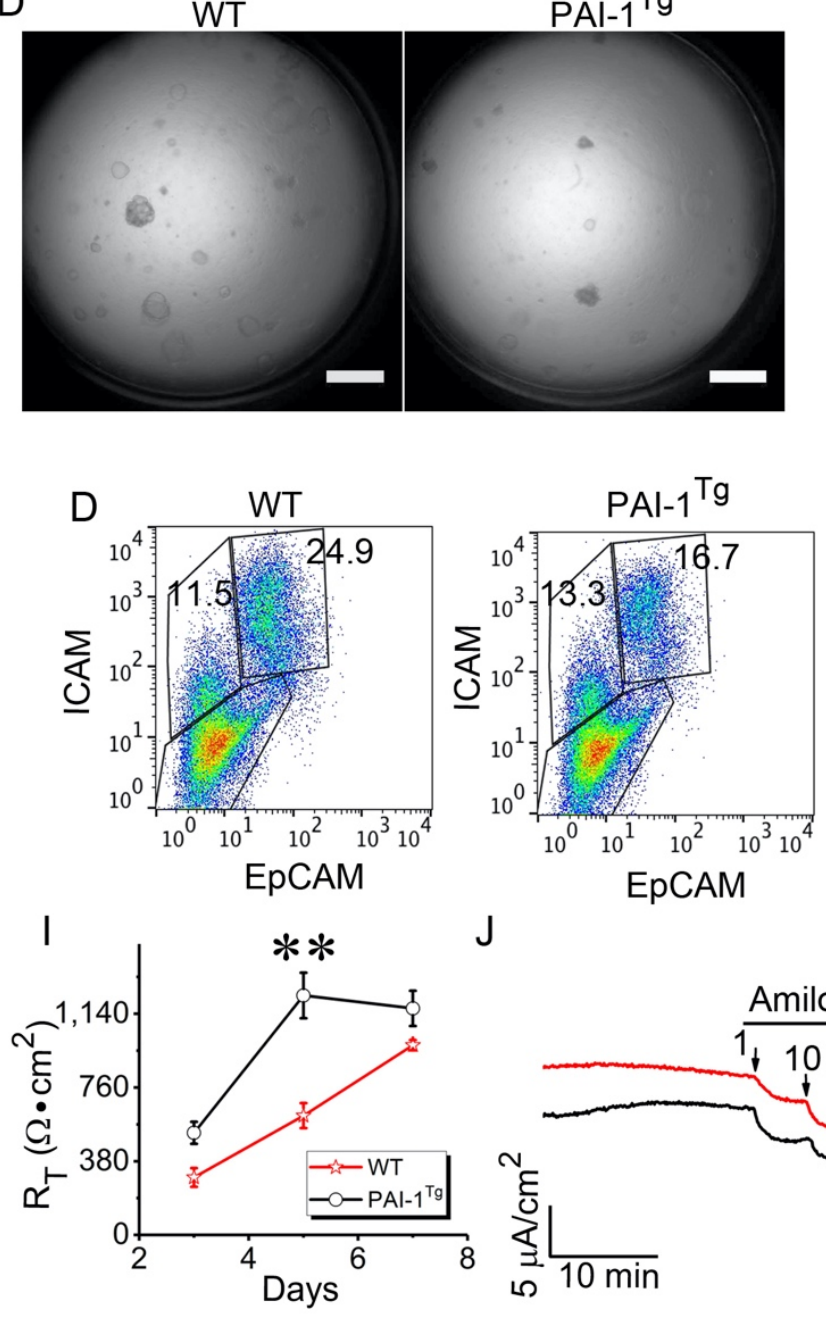

J

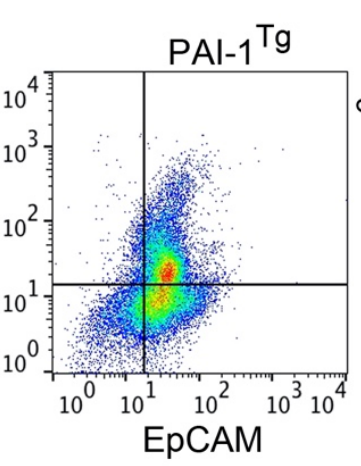

E
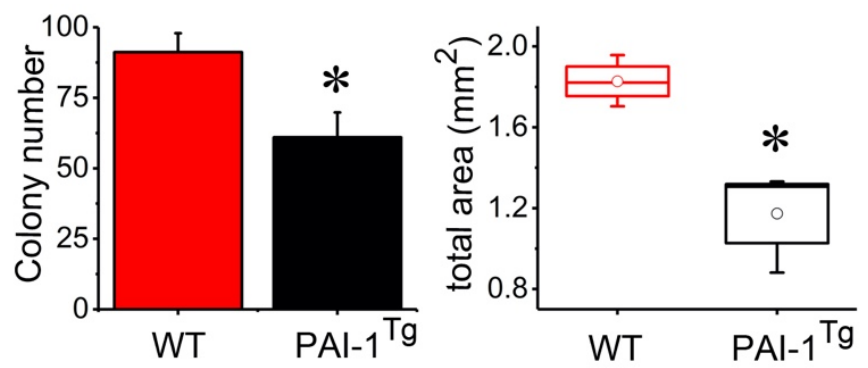

$\mathrm{H}$

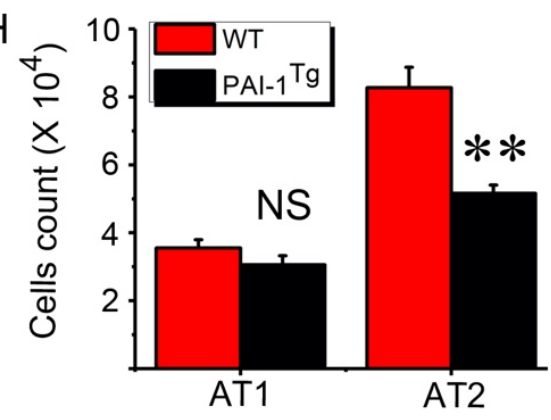

K

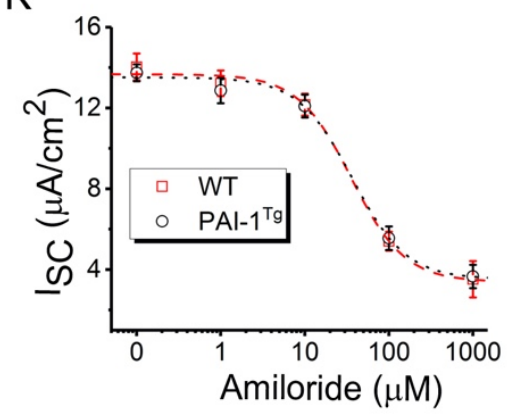


Supplementary file

\section{MATERIALS \& METHODS}

\section{Cells, antibodies, reagents, and key materials}

Major critical reagents are listed in the table. General chemicals and reagents were purchased from Sigma.

\begin{tabular}{|c|c|c|c|}
\hline Name & Manufacture & Catlog \# & Experiments \& Concentration \\
\hline $\mathrm{DMEM} / \mathrm{F} 12$ & Sigma & D6421 & $\begin{array}{l}\text { Mouse AT2 isolation, AT2 monolayer and } \\
\text { organoid cultures }\end{array}$ \\
\hline $\begin{array}{l}\text { Dynabeads myone } \\
\text { streptavidin T1 }\end{array}$ & Invitrogen, USA & 65601 & Mouse AT2 isolation, $2.5 \mu \mathrm{L} / 10^{6}$ cells \\
\hline ALK inhibitor & Abcam & Ab120163 & Organoid culture, $10 \mu \mathrm{M}$ \\
\hline $\begin{array}{l}\text { Insulin selenium transferrin } \\
\text { (ITS) }\end{array}$ & Gibco & $41400-045$ & Organoid culture, $10 \%$ \\
\hline L-glutamine & MP Biomedicals & 194678 & AT2 monolayer and organoid culture, $2 \mathrm{mM}$ \\
\hline Primocin & InvivoGen, USA & Ant-pm-1 & AT2 monolayer culture, $100 \mu \mathrm{g} / \mathrm{mL}$ \\
\hline $\begin{array}{l}\text { Growth factor reduced } \\
\text { Matrigel }\end{array}$ & Corning & 354230 & Organoid culture, $1: 1$ ratio with medium \\
\hline Mlg 2908 cells & ATCC & CCL-206 & $\begin{array}{l}\text { Organoid culture, } 2 \times 10^{5} \text { cells mixed with } \\
6,000 \text { AT } 2 \text { cells }\end{array}$ \\
\hline Insulin selenium transferrin & Roche & 11074547001 & Monolayer culture, $0.05 \%$ \\
\hline Non-essential amino acids & GE Healthcare & SH3023801 & $\begin{array}{l}\text { Complete mouse medium for monolayer } \\
\text { culture, } 0.01 \mathrm{mM} \text { or } 1 \times\end{array}$ \\
\hline Mouse laminin1 & Trevigen & $3401-010-02$ & Coating for AT2 monolayer culture, $10 \mu \mathrm{g} / \mathrm{cm}^{2}$ \\
\hline Rat collagen I & Trevigen & $3440-005-01$ & $\begin{array}{l}\text { AT2 monolayer culture \& human AT2 sorting, } \\
10 \mu \mathrm{g} / \mathrm{cm}^{2}\end{array}$ \\
\hline Mouse IgG & Sigma & $\mathrm{I} 5381$ & Mouse AT2 isolation, $50 \mu \mathrm{g} / \mathrm{mL}$ \\
\hline DNase I & Sigma & D25 & Human and mouse AT2 isolation, $0.1 \mathrm{mg} / \mathrm{ml}$ \\
\hline Dispase & Corning & 354235 & $\begin{array}{l}\text { Human and mouse AT2 isolation, } 50 \mathrm{U} / \mathrm{mL} \text {, } \\
\text { organoid dissociation, } 10 \mathrm{U} / \mathrm{mL}\end{array}$ \\
\hline Low melting point agarose & Sigma & A9414 & Mouse AT2 isolation, $1 \%$ \\
\hline $\begin{array}{l}\text { Biotin rat anti-mouse } \\
\text { CD16/32 }\end{array}$ & $\mathrm{BD}$ & 553143 & Mouse AT2 isolation, $0.65 \mu \mathrm{g} / 10^{6}$ cells \\
\hline Biotin rat anti-mouse CD45 & $\mathrm{BD}$ & 553078 & Mouse AT2 isolation, $1.5 \mu \mathrm{g} / 10^{6}$ cells \\
\hline $\begin{array}{l}\text { Biotin rat anti-mouse Ter- } \\
119\end{array}$ & $\mathrm{BD}$ & 553672 & Mouse AT2 isolation, $5 \mu \mathrm{g} / 10^{6}$ cells \\
\hline Click-iT $^{\mathrm{TM}}$ EdU AF488 kit & Invitrogen & C10337 & EdU essay for DNA synthesis \\
\hline Hematoxylin & Fisher Scientific & SH26-500D & Pap stain \\
\hline $\begin{array}{l}\text { Anti-SFTPC polyclonal } \\
\text { antibody }\end{array}$ & $\begin{array}{l}\text { ThermoFisher } \\
\text { Scientific }\end{array}$ & PA5-71680 & IF, $1: 500$ \\
\hline $\begin{array}{l}\text { Podoplanin monoclonal } \\
\text { antibody }(8.1 .10)\end{array}$ & $\begin{array}{l}\text { ThermoFisher } \\
\text { Scientific }\end{array}$ & MA5-16113 & IF, $1: 300$ \\
\hline $\begin{array}{l}\text { Podoplanin monoclonal } \\
\text { antibody }\end{array}$ & Abcam & $\mathrm{AB} 10288$ & IF, $1: 100$ \\
\hline Anti-proSP-C & EMD Millipore & AB3786 & IF, $1: 100$ \\
\hline $\begin{array}{l}\text { APC anti-mouse/human } \\
\text { CD44 }\end{array}$ & Biolengend & 103012 & IF, $1: 500$ \\
\hline Goat anti-rabbit IgG AF488 & $\begin{array}{l}\text { Jackson } \\
\text { ImmunoResearch }\end{array}$ & $111-545-045$ & IF, $1: 1000$ \\
\hline $\begin{array}{l}\text { Goat anti-hamster IgG } \\
\text { AF568 }\end{array}$ & ThermoFisher & A-21112 & IF, $1: 1000$ \\
\hline Goat anti-mouse IgG AF568 & ThermoFisher & A-11004 & IF, $1: 1000$ \\
\hline
\end{tabular}


Supplementary file

\begin{tabular}{|l|l|l|l|}
\hline $\begin{array}{l}\text { APC anti-mouse/human } \\
\text { CD44 }\end{array}$ & Biolengend & 103012 & FACS sorting for CD44 ${ }^{+}$cells, $0.4 \mu \mathrm{g} / 10^{6}$ cells \\
\hline AF488 anti-mouse CD326 & Biolengend & 118210 & FACS sorting for AT2 cells, $4.0 \mu \mathrm{g} / 10^{6}$ cells \\
\hline APC anti-mouse podoplanin & Biolengend & 127410 & FACS analysis for AT1 cells, $0.5 \mu \mathrm{g} / 10^{6}$ cells \\
\hline $\begin{array}{l}\text { Anti-mouse CD44 blocking } \\
\text { antibody }\end{array}$ & R\&D System & AF6127 & FACS and IHC, $30 \mathrm{ng} / \mathrm{mL}$ \\
\hline Collagen IV & Trevigen & $3410-010-01$ & Coating for AT2 culture, $10 \mu \mathrm{g} / \mathrm{cm}^{2}$ \\
\hline A6 peptide & GeneScript & Synthesized & Differentiation assay, $1 \mu \mathrm{M}$ \\
\hline Scrambled A6 peptide & GeneScript & Synthesized & Differentiation assay, $1 \mu \mathrm{M}$ \\
\hline Elastase & Worthington & LS002280 & human AT2 isolation, $13 \mathrm{U} / \mathrm{mL}$ \\
\hline DNase I & Roche & 10104159001 & human AT2 isolation, $500 \mu \mathrm{g} / \mathrm{mL}$ \\
\hline IgG from human serum & Sigma & I4506 & human AT2 isolation \\
\hline Percoll & Sigma & P7828 & human AT2 isolation, $1.04 \mathrm{and} 1.09 \mathrm{~g} / \mathrm{mL}$ \\
\hline Influenza A/PR/8/34 H1N1 & Charles River & 10100781 & Influenza infection, $3,660 \mathrm{pfu} / \mathrm{mouse}$ \\
\hline
\end{tabular}

\section{Animal husbandry}

All mice purchased from Jackson Laboratory were maintained in a pathogen-free facility. A 12-h light/dark cycle and ad libitum supply for food and water were provided. Age, sex, and weight-matched (4-12 months) wild type (wt), Plau ${ }^{-/}$, and Sepine ${ }^{T g}$ mice were sacrificed for experiments as approved by the Institute of Animal Care and Use Committee of the University of Texas Health Science Center at Tyler.

\section{Influenza-induced lung injury and immunohistology}

Wt and $\mathrm{Plau}^{--}$mice were infected intranasally with a dose of 3,660 pfu influenza virus (type A/PR8/34 H1N1, Charles River, USA) diluted in $50 \mu \mathrm{l}$ PBS per anesthetized animal. Control animals were delivered intranasally with the same amount of PBS. Both control and infected mice were euthanized $5 \mathrm{~d}$ post infection. The trachea was tied with a suture followed by opening the chest cavity and removing the lungs subsequently. The dissected lungs were fixed with 10\% neutral buffered formalin v/v (Richard-Allan Scientific) for $72 \mathrm{~h}$ at room temperature. Lung tissues were then dehydrated with increasing ethanol grades, embedded in paraffin, and sectioned at a thickness of $7 \mu \mathrm{m}$.

\section{Visualization and quantification of AT2 cells in mouse and human lung tissues}

Lung sections from both influenza-infected mice and brain dead patients who had ARDS based on the Berlin criteria were deparaffinized and rehydrated in xylene and a series of ethanol at cumulating concentrations and in $\mathrm{H}_{2} \mathrm{O}$ for 5 min. To unmask antigens, tissue slides were incubated with $10 \mathrm{mM}$ sodium citrate buffer (Thermo 


\section{Supplementary file}

Scientific), $\mathrm{pH} 6.0$, for $20 \mathrm{~min}$ at $95^{\circ} \mathrm{C}$, cooled for another $20 \mathrm{~min}$ at room temperature, and then washed with

PBS. After blocking for $1 \mathrm{~h}$ with $1 \% \mathrm{BSA}$ and 4\% normal goat serum, tissue sections were incubated with following antibodies: anti-proSP-C (1:500, EMD Millipore), anti-pdpn (1:300, ThermoFisher) for mouse lung tissues and 1:100 dilution for both antibodies (Abcam) for human lung slices. After 3 times washing with PBS, secondary antibodies were applied: goat anti-rabbit IgG AF488, goat anti-hamster AF568, and goat anti-mouse AF568. Tissue sections were stained with DAPI and sealed. Images were captured using a Zeiss LSM 510 confocal microscope. Images were captured containing at least 7 - 8 individual $1 \mu \mathrm{m}$ optical Z-sections. Z-stacks were obtained from at least five randomly selected areas. All images were subsequently processed with ImageJ software. AT2 cells were counted using a cell counter plug-in for ImageJ software. Cells were counted in at least 5 different areas to obtain a total above 1,000 cells and then analyzed statistically.

\section{Mouse AT2 isolation}

Mouse AT2 cells were isolated from wt, $\mathrm{Plau}^{-/}$, and Sepine ${ }^{T g}$ strains of C57BL/6 animals (Jackson Laboratory, USA) as previously reported with modifications1. Briefly, mice were euthanized and exsanguinated, followed by perfusing lungs with $10-20 \mathrm{~mL}$ DPBS until pink lungs turned to white. The trachea was cannulated with a $20 \mathrm{G}$ catheter to instill $1.5-2.0 \mathrm{~mL}$ dispase followed by $0.5 \mathrm{~mL}$ of $1 \%$ low melting point agarose. The lungs were dissected and incubated in $50 \mathrm{U} / \mathrm{mL}$ dispase solution for $45 \mathrm{~min}$ at room temperature. The lungs were gently teased in DMEM/F-12+0.01\% DNase I and incubated for $10 \mathrm{~min}$ at room temperature. Cells were passed through a serial filtration $(100,40,30$, and $10 \mu \mathrm{m}$ cell strainers $)$ and centrifuged at $300 \times \mathrm{g}$ for $10 \mathrm{~min}$ at $4^{\circ} \mathrm{C}$. Cells were resuspended in $10 \mathrm{~mL}$ medium $(\mathrm{DMEM} / \mathrm{F}-12+10 \% \mathrm{FBS}+\mathrm{P} / \mathrm{S})$ supplemented with biotinylated antibodies, rat anti-mouse CD16/32 (0.65 $\mu \mathrm{g} /$ million cells), rat anti-mouse CD45 (1.5 $\mu \mathrm{g} / \mathrm{million}$ cells), and rat anti-mouse Ter1 $19(5 \mu \mathrm{g})$ and incubated for $30 \mathrm{~min}$ at $37^{\circ} \mathrm{C}$ on an incubator shaker at $60 \mathrm{rpm}$. Resuspended cells were then incubated with pre-washed streptavidin-coated magnetic particles for $30 \mathrm{~min}$ at room temperature to remove undesired cells. Selected cells were then resuspended in $10 \mathrm{~mL}$ medium (DMEM/F-12 $+10 \% \mathrm{FBS}+\mathrm{P} / \mathrm{S})$ and incubated for $30 \mathrm{~min}$ at $37^{\circ} \mathrm{C}$ in a sterile Petri dish to allow residual fibroblasts to adhere to the bottom of the dish. Suspended cells were transferred in plates pre-coated with mouse IgG for $2 \mathrm{~h}$ in a $5 \% \mathrm{CO}_{2}$ incubator to remove 
Supplementary file

macrophages. Unattached cells were collected and centrifuged at $300 \times \mathrm{g}$ for $10 \mathrm{~min}$ at $4^{\circ} \mathrm{C}$. Cell pellets were then resuspended in a complete mouse medium (CMM: DMEM/F-12 supplemented with 2 mM L-glutamine, $0.25 \%$ bovine serum albumin, $10 \mathrm{mM}$ HEPES, $0.1 \mathrm{mM}$ non-essential amino acids, $0.05 \% \mathrm{ITS}, 100 \mu \mathrm{g} / \mathrm{mL}$ primocin, and $10 \%$ newborn calf serum). The viability of harvested AT2 cells was assessed by the trypan blue exclusion assay followed by cell counting for the yield.

The purity of isolated AT2 cells was confirmed by the Papanicolaou stain, immunofluorescent staining with antiproSP-C antibody, and fluorescence-activated cell sorting (FACS) with anti-EpCAM antibody. 1) PAP stain: freshly isolated AT2 cells suspended in DPBS $+10 \%$ FBS $\left(2 \times 10^{5}\right.$ cells $\left./ \mathrm{mL}\right)$ were centrifuged at $600 \mathrm{rpm}$ for 4 min by a Shandon CytoCentrifuge. Slides were air-dried overnight and stained using a modified PAP stain method2. Briefly, slides were stained with hematoxylin for $3.5 \mathrm{~min}$. After rinsing in $\mathrm{dH}_{2} \mathrm{O}$, slides were incubated in lithium carbonate for 2 min and rinsed with $\mathrm{dH}_{2} \mathrm{O}$ again. Slides were dehydrated in serial ethanol dilutions, then in xylene: ethanol (1:1) for $30 \mathrm{~s}$, and finally in 100\% xylene for $60 \mathrm{~s}$. Slides were mounted with the Permount mounting medium. Randomly selected images were captured from 6 independent experiments with an Olympus BX41 microscope $(40 \times)$. AT2 cells with large nuclei and blue colored granules spread in the cytoplasm were counted and calculated for purity (\%). 2) Immunofluorescent stain: cytospanned freshly isolated AT2 cells and cells cultured on coverslips for $48 \mathrm{~h}$ were incubated with rabbit anti-proSP-C (1:500) overnight at $4^{\circ} \mathrm{C}$. Secondary antibody, either Alexa Flour 488 or 568-conjugated anti-rabbit IgG, was added to recognize proSP-C antibody. 3) FACS: Briefly, cells were resuspended in staining buffer containing 0.1 mM EDTA. Cells were incubated with Alexa Fluor 488 conjugated anti-mouse CD326 for 30 min on ice in the dark. Cells were washed and resuspended in staining buffer and analyzed for antibody expression on BD FACSCalibur ${ }^{\mathrm{TM}}$. Data were analyzed with FlowJo 10.1 software. The purity of the final cell suspensions was about 93\% (Fig. S1A-C). Cell viability was approximately 94\%. Further, FACS showed that approximately 95\% of cells were EpCAM positive (Fig. S1DE).

\section{Human AT2 isolation}


Supplementary file

Human epithelial AT2 cells were isolated from six human lungs not used for transplantation by the Northern California Transplant Donor Network as previously described3, 4. Three of the lungs were normal and three of the lungs met ARDS criteria before they were harvested. After cold preservation at $4^{\circ} \mathrm{C}$, the right middle lobe was selected for cell isolation if no apparent signs of consolidation or hemorrhage by gross inspection were seen. The pulmonary vasculature was first flushed antegrade and retrograde with PBS to remove the remaining blood from the microcirculation. The distal airspaces were then lavaged 10 times with $\mathrm{Ca}^{2+}, \mathrm{Mg}^{2+}$-free PBS solution $\left(37^{\circ} \mathrm{C}\right)$ containing $0.5 \mathrm{mM}$ EGTA and $0.5 \mathrm{mM}$ EDTA. Elastase, $13 \mathrm{U} / \mathrm{mL}$ in $\mathrm{Ca}^{2+}, \mathrm{Mg}^{2+}$-free Hanks' balanced salt solution, was instilled into the distal airspaces by segmental bronchial intubation. The lobe was then digested at $37^{\circ} \mathrm{C}$ for $45-60 \mathrm{~min}$. After digestion, the lobe was further minced in the presence of FBS and DNase I (500 $\mu \mathrm{g} / \mathrm{mL})$. The cell-rich fraction was filtered sequentially through multiple layers of sterile gauze and 100- and 20$\mu \mathrm{m}$ nylon meshes (Spectra/Mesh). The filtrate was further layered onto a discontinuous Percoll (Sigma) density gradient of 1.04 and $1.09 \mathrm{~g} / \mathrm{mL}$ solution and centrifuged at $400 \times \mathrm{g}$ for $20 \mathrm{~min}$. The interface containing both AT2 cells and alveolar macrophages was collected and further centrifuged at $800 \mathrm{rpm}$ for $10 \mathrm{~min}$, and the cell pellet was washed and resuspended in $\mathrm{Ca}^{2+}, \mathrm{Mg}^{2+}$-free PBS containing 0.5\% FBS. The cells were incubated with magnetic beads coated with anti-CD 14 antibodies (Dynabeads ${ }^{\circledR}$ CD14, Invitrogen) at 4 C for 40 min, and the majority of the macrophages were then selectively depleted with a Dynal magnet (Dynal Biotech, Oslo, Norway). The cell suspension was further incubated on Petri dishes coated with human IgG antibodies (Sigma) overnight at $37^{\circ} \mathrm{C}$ to remove the remaining macrophages and fibroblasts. Cell viability was assessed by the trypan blue exclusion method. AT2 cell purity was evaluated by Papanicolaou (Pap) staining.

\section{$\mathrm{CD}^{+}{ }^{+}$AT2 cells sorting and analysis by FACS}

Freshly isolated cells were seeded on either collagen IV (for mouse AT2, $10 \mu \mathrm{g} / \mathrm{cm}^{2}$ ) or collagen I (for human AT2, $10 \mu \mathrm{g} / \mathrm{cm}^{2}$ ) coated plates for $24-36 \mathrm{~h}$ to revive CD44 expression diminished by digestive enzymes. Both unattached and attached (trypsinized) cells were collected and blocked with $1 \%$ BSA, 4\% normal goat serum in PBS. Cells were stained with AF488-EpCAM (BioLegend), APC anti-human CD44 (BioLegend), and their respective isotypes. Cells were sorted using a Beckman Coulter MoFlo high-speed cell sorter. Unstained, isotype 
Supplementary file

and single-color controls were performed. The gates for CD44 and EpCAM were set based on the results of isotype, and single-color controls were run in parallel. The results were analyzed using FlowJo 10.1 software.

\section{D polarized AT2 monolayers and geometrical measures}

Transwell inserts (Costar 3470: $0.4 \mu \mathrm{m}$ pore size, $0.33 \mathrm{~cm}^{2}$ area; Corning Costar, USA) were pre-coated with mouse laminin 1 at $10 \mu \mathrm{g} / \mathrm{cm}^{2}$ (for mouse AT2 cells; Trevigen, USA) for $4-6 \mathrm{~h}$ at $37^{\circ} \mathrm{C}$ or with rat tail collagen I at $10 \mu \mathrm{g} / \mathrm{cm}^{2}$ (for human AT2 cells; Trevigen, USA) for $1 \mathrm{~h}$ at $37^{\circ} \mathrm{C}$. Freshly isolated AT2 cells were seeded at $10^{6}$ cells $/ \mathrm{cm}^{2}$. The CMM medium $(600 \mu \mathrm{L})$ was added to the basolateral side of each transwell. The culture medium on the basolateral side was replaced with a serum-free medium in $48 \mathrm{~h}$ post seeding. Transepithelial resistance $\left(\mathrm{R}_{\mathrm{T}}, \Omega\right)$ and potential difference $\left(\mathrm{V}_{\mathrm{T}}, \mathrm{mV}\right)$ were measured using an epithelial voltohmmeter (EVOM: World Precision Instrument, USA) in $72 \mathrm{~h}$. The culture medium was then replaced with serum-free media and maintained with the air-liquid interface until day 5. Monolayers were maintained in a humidified $5 \% \mathrm{CO}_{2}$ air incubator at $37^{\circ} \mathrm{C}$. Stacked image files (avi format) were segmented with 3D Objects Counter. Surface files were used for both 3D geometrical and shape measures. The 3D surface plot was used to generate surface graphs. This 3D model has the following advantages: 1) Stromal cells are not used (feeder-free). 2) Tight junction proteins are generated to develop an epithelial barrier in an in vivo pattern. 3) Cells are polarized to separate apical and basolateral membranes. 4) Cytosolic and cell surface signal proteins are expressed and distributed in a polarized way. 5) It is suitable for testing the permeability of the epithelial barrier. 6) It complimentarily overcomes the limitations of 3D organoids for studying barrier function and polarization of signaling proteins.

\section{Measurements of bioelectric properties in AT2 monolayers}

Transepithelial short-circuit current $\left(\mathrm{I}_{\mathrm{SC}}, \mu \mathrm{A} / \mathrm{cm}^{2}\right)$ in AT2 monolayers was measured with an 8-channel voltageclamp amplifier (Physiological instruments, USA) as previously described5. Briefly, AT2 monolayers were mounted in the vertical Ussing Chambers bathed with solutions containing (in $\mathrm{mM}$ ): $120 \mathrm{NaCl}, 25 \mathrm{NaHCO}_{3}, 3.3$ $\mathrm{KH}_{2} \mathrm{PO}_{4}, 0.83 \mathrm{~K}_{2} \mathrm{HPO}_{4}, 1.2 \mathrm{CaCl}_{2}, 1.2 \mathrm{MgCl}_{2}, 10 \mathrm{HEPES}, 10$ mannitol (apical compartment), or $10 \mathrm{D}$-glucose (basolateral compartment). Each solution was iso-osmotic. The transwell cultures were bubbled continuously with a gas mixture of $95 \% \mathrm{O}_{2}-5 \% \mathrm{CO}_{2}$. The transmonolayer potential was short-circuited to $0 \mathrm{mV}$, and a $10-\mathrm{mV}$ pulse 
Supplementary file

of 1-s duration was imposed every $10 \mathrm{~s}$ to monitor transepithelial resistance. Data were collected with the Acquire and Analyze program (version 2.3; Physiologic Instruments). When the Isc level reached a plateau, compounds were pipetted to the apical compartment.

\section{D organotypic cultures of AT2 cells}

AT2 cells were cultured as organoids as previously described6. Briefly, Mlg-2908 cells $\left(2 \times 10^{5}\right.$ cells $\left./ \mathrm{mL}\right)$ were mixed with 6,000 primary AT2 cells and pelleted down for each transwell. Cells were then resuspended into a $100 \mu \mathrm{L}$ mixture (1:1) of growth factor reduced matrigel (Corning, USA) and organoid medium (DMEM/F12 supplemented with $2 \mathrm{mM}$ L-glutamine, $10 \%$ active FBS, $1 \%$ ITS, and $10 \mu \mathrm{M}$ ALK inhibitor). On each $0.33 \mathrm{~cm}^{2}$ insert (Corning Costar, USA) $50 \mathrm{uL}$ mixed cells were seeded and incubated at $37^{\circ} \mathrm{C}$ for 30 min to allow the matrix to solidify. Then $410 \mu \mathrm{L}$ culture medium was added to the bottom well and changed half $(200 \mu \mathrm{L})$ of the medium every other day. The DIC images of organoids (diameter $\geq 50 \mu \mathrm{m}$ ) were visualized with an Olympus IX 73 microscope (4× objective, Olympus, Japan) with an Hamamatsu photonics CMOS camera (Orca Flash 4.0; 2,048 $\times 2,048$ pixels) on a designed day post seeding. The surface area of individual organoid was measured with Image

J. The sum of all organoids on each transwell insert was the total surface area. Histologic images of organoids were captured from sliced matrigel. Matrigel containing organoids was fixed with 4\% paraformaldehyde in PBS for $1 \mathrm{~h}$, dehydrated with increasing ethanol grades, and embedded in paraffin blocks. Sections at the thickness of $7 \mu \mathrm{m}$ were fixed for an additional $5 \mathrm{~min}$ in 4\% paraformaldehyde, then $\mathrm{H} \& \mathrm{E}$ stain was performed as described previously7.

\section{Quantification of AT1 and AT2 cells in organoids and monolayers}

Anti-pdpn and anti-sftpc antibodies were used to detect AT1 and AT2 cells, respectively. Fluorescence conjugated secondary antibodies, goat anti-hamster AF568 and goat anti-rabbit IgG AF488 were used. Fluorescent images were projected with a Zeiss LSM 510 confocal microscope and stacked with a Fiji plug-in for ImageJ. Monolayers and organoids were scanned for $\mathrm{Z}$ sections with optimal depth from top to bottom. Images were stacked for pdpn and sftpc signal separately to count the number of positive cells precisely with a cell counter plug-in of ImageJ. 
Supplementary file

Alternatively, cells were collected from organoids and monolayers and sorted by FACS. Each slide was scanned for at least 6 different fields ( $\mathrm{n}=3$ animals/experiments). For 3D organoids, all $\mathrm{Z}$ sections were stacked from top to bottom and saved as .avi files.

\section{EdU assay for DNA synthesis}

AT2 cells with active DNA synthesis in organoids and monolayers were detected with a Click-iT ${ }^{\mathrm{TM}}$ EdU assay kit. Organoids and monolayers from both wt and Plau $^{-/-}$groups were stained with the Click-iT ${ }^{\mathrm{TM}}$ EdU Alexa flour 488 following the manufacturer's instructions. Images were captured and analyzed for the percentage of EdU ${ }^{+}$ cells in different experimental groups. Ten randomly selected images across the monolayer from 3 independent experiments were captured and counted for total cells and $\mathrm{EdU}^{+}$portion. For organotypic cultures, all 3 organoid types were scanned $(n=5$ colonies for each type). The $\mathrm{z}$ sections were stacked separately for DAPI (blue) and EdU (green) to produce a 3D structure of organoids for counting total and EdU ${ }^{+}$cells, respectively, using a cell counter plug-in for the ImageJ. The percentage of EdU ${ }^{+}$cells was calculated for each group, and the difference among groups was compared statistically.

\section{Application of A6 peptide and CD44-blocking antibody to organoids}

A6 and scrambled A6 (sA6) peptides were synthesized by Genscript. Stock solutions (2 mM) were prepared by dissolving peptides in water according to the manufacturer's instruction. For 3D matrigel cultures, sorted Plau ${ }^{-/-}$ AT2 cells were preincubated with either A6 or sA6 peptide $(1 \mu \mathrm{M})$ for $30 \mathrm{~min}$ at room temperature. Wt AT2 cells were treated with $30 \mathrm{ng} / \mathrm{mL}$ CD44-blocking antibody for $30 \mathrm{~min}$ at room temperature. The same concentrations of A6, sA6 peptides, and CD44-blocking antibody were added to both the matrigel/medium mix and the culture medium placed under the transwell inserts. The culture medium was changed every $48 \mathrm{~h}$.

\section{Organoid dissociation and FACS}

For analysis of AT2 cell proliferation and differentiation, AT2 organoids from different experimental groups were isolated from matrigel with dispase $(10 \mathrm{U} / \mathrm{mL})$ and dissociated in $0.25 \%$ trypsin-EDTA to get a single-cell suspension. Cells were then stained with antibodies AF488 conjugated EpCAM, APC conjugated ICAM, and APC conjugated PDPN. Gates for both colors were set by unstained cells and isotype controls for each antibody. 
Supplementary file

We have used a strategy to use double color staining to enhance the separation of AT1 and AT2 cells in the cell suspension of organoids. Cells were analyzed by FACSCaliber ${ }^{\mathrm{TM}}$ (BD, USA), and the results were analyzed using FlowJow 10.1 software.

\section{Statistical analysis}

Data were presented as mean \pm s.e.m. No animals were excluded. Normality tests were performed to determine whether the data were parametric or not. If the data were normally distributed and the variance between groups was not significantly different, mean differences in measured variables between the experimental and control group were assessed with the Student's two-tailed t-tests or one-way ANOVA followed by the Tukey's or Bonferroni's post hoc test. Otherwise, the Mann-Whitney U test was applied for analyzing non-parametric results. Two-way ANOVA followed by Sidak's multiple-comparison test was used for multiple comparisons. Meanwhile, the actual power of the sample size was analyzed. Mean differences were considered statistically significant at the levels of $\mathrm{P}<0.05, \mathrm{P}<0.01$ and $\mathrm{P}<0.001$. Origin Pro 2018 was used for statistical analysis and plotting. 
Supplementary file

\section{Figure Legends:}

Figure S1. Cytological characterization of mouse alveolar type 2 (AT2) epithelial cells. The viability of isolated AT2 cell preparations was examined with trypan blue assay, then for its purity with pap staining, immunostaining with anti-sftpc antibody, and FACS analysis. A. Representative AT2 cell image of pap stain showing featured cytoplasmic granules. A total of 1,000 cells counted to calculate the purity. B-C. Representative immunostaining images of cytospanned (B) and cultured AT2 cells post $72 \mathrm{~h}(\mathrm{C})$, respectively, probed with an anti-pro-surfactant protein C (pro-SPC) antibody. Nuclei were counterstained with Hoechst dye (blue). D-E. The purity of freshly harvested mouse AT2 cells was analyzed with FACS. Cells were incubated with an anti-EpCAM antibody. Scale bar in B, C, and D is $100 \mu \mathrm{m}$. Data in a is mean \pm sem and analyzed with the Student t-test. ***indicates $\mathrm{P}<0.001$ vs wild type (wt) controls. (Files: 08212017 D12 Phase Contrast 4X. uPA vs WT organoids for CFE Day8 and Day12, origin pro file).

Figure S2. Comparison of AT2 organoids between wt and Plaw ${ }^{-/-}$groups 12 days post planting in 3D matrigel. A. DIC images. Phase-contrast images were captured $(4 \times)$. Scale bar, $1 \mathrm{~mm}$. B. Colony-forming efficiency $(\mathrm{CFE}$, left), counting (middle), and surface area (right). Colonies with a diameter of $<50 \mu \mathrm{m}$ were not counted. $* * * \mathrm{P}<$ 0.001 and $* * \mathrm{P}<0.01$ vs controls. $\mathrm{n}=7$. (File: $08212017 \mathrm{D} 12$ Phase Contrast $4 \times$; project interim summary of Nov 2017.key. uPA vs WT organoids for CFE Day8 and Day12.opj.)

Figure S3. Measurement of organoid permeability. A. Organoid images with live-cell cytotracker calcien green at 0 (left) and $30 \mathrm{~min}$ (right) after addition of forskolin (10 $\mu \mathrm{M}$, CFTRinh $20 \mu \mathrm{M}$, and amiloride $100 \mu \mathrm{M})$. Full length, $200 \mu \mathrm{m}$. B. Surface area of organoids. $\mathrm{n}=8$. NS, not significant. (File: AT2 D7 organoid 100um forskolin calcien green. Normalized area of AT2 organoids treated with forskolin amiloride and CFTR.ppt.) 
Supplementary file

Figure S4. 3D video clips of organoids stained with EdU. Representative organoids of wt (left) and Plau ${ }^{-/-}$(right) AT2 cells were imaged (x-y), stacked of z sections, and visualized by the ImageJ. EdU ${ }^{+}$cells were stained as green nuclei. The volume was 9,111 and 2,806 voxels for wt and Plau $u^{-/-}$organoids, respectively. The geometrical surface area was 41,380 (wt) and 12,828 pixels $\left(\right.$ Plau $\left.^{-/}\right) . \mathrm{n}=6$. (File name: 12222017 EdU Staining D6 organoid wt vs plau ko. Avi or tif files.)

Figure S5. Effects of A6 peptide and CD44 blocking antibody on the formation of AT2 organoids. A. Representative DIC images of AT2 organoids. From left to right, wt control organoids (WT), wt organoids treated with CD44 blocking antibody (CD44 Ab), Plaü ${ }^{-/-}$AT2 organoids (Plaur-/), and Plau ${ }^{-/-}$organoids treated with A6 peptide (A6). $4 \times$. B. Organoid number. $\mathrm{n}=6$ replicates per experiment, $\mathrm{n}=6$ mice/genotype. ${ }^{*} \mathrm{P}<0.05$ and ${ }^{* *} \mathrm{P}$ $<0.01$ vs controls. C. Surface area of organoids. $* \mathrm{P}<0.05$ and $* * \mathrm{P}<0.01$ vs controls. $\mathrm{n}=6$. Data in $\mathrm{B} \& \mathrm{C}$ were mean \pm sem and analyzed by Student's t-test. (File names: Supp fig for fig 7.jpg.)

Figure S6. Analysis of polarized AT2 monolayers. A. Visualization of polarized tight mouse AT2 monolayers for wt (top) and Plau-- (bottom) mice. From left to right were images of nuclei (DAPI), AT1 cells (Pdpn), AT2 cells (Sftpc), and merged images. Scale bar, $50 \mu \mathrm{m}$. B. Comparison of AT1 and AT2 cells between wt and Plau ${ }^{\prime}$ monolayers. $\mathrm{n}=6 . * \mathrm{P}<0.05$ and $* * \mathrm{P}<0.01$ vs wt controls. C. 3D surface plots. D-E. 3D geometrical measures for volume (D) and surface area (E). $\mathrm{n}=5$ for wt and $\mathrm{n}=8$ for Plau ${ }^{-/}$group. NS, no significant. (File name: Figure S7 folder).

\section{References}

1. Demaio, L. et al. Characterization of mouse alveolar epithelial cell monolayers. Am J Physiol Lung Cell Mol Physiol 296, L1051-1058 (2009).

2. Dobbs, L.G. Isolation and culture of alveolar type II cells. Am J Physiol 258, L134-147 (1990). 
Supplementary file

3. Fang, X., Neyrinck, A.P., Matthay, M.A. \& Lee, J.W. Allogeneic human mesenchymal stem cells restore epithelial protein permeability in cultured human alveolar type II cells by secretion of angiopoietin-1. $J$ Biol Chem 285, 26211-26222 (2010).

4. $\quad \mathrm{Yu}, \mathrm{W}$. et al. Formation of cysts by alveolar type II cells in three-dimensional culture reveals a novel mechanism for epithelial morphogenesis. Mol Biol Cell 18, 1693-1700 (2007).

5. Demaio L, T.W., Balverde Z, Alvarez JR, Kim KJ, Kelley DG, Senior RM, Crandall ED, Borok Z. Characterization of mouse alveolar epithelial cell monolayers. Am J Physiol Lung Cell Mol Physiol 296, L1051-L1058 (2009).

6. Liang, J. et al. Hyaluronan and TLR4 promote surfactant-protein-C-positive alveolar progenitor cell renewal and prevent severe pulmonary fibrosis in mice. Nat Med 22, 1285-1293 (2016).

7. Kaisani, A. et al. Branching morphogenesis of immortalized human bronchial epithelial cells in threedimensional culture. Differentiation 87, 119-126 (2014). 
Supplementary file

Figure S1.

A

B

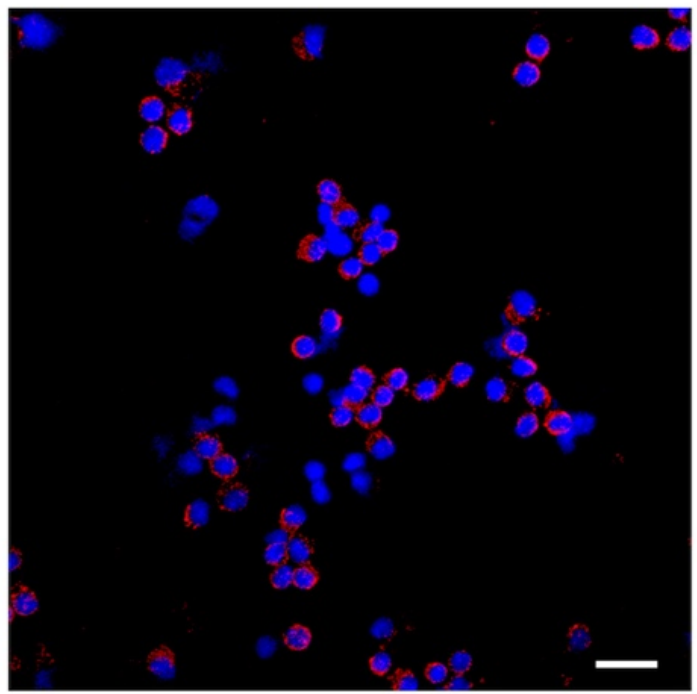

D

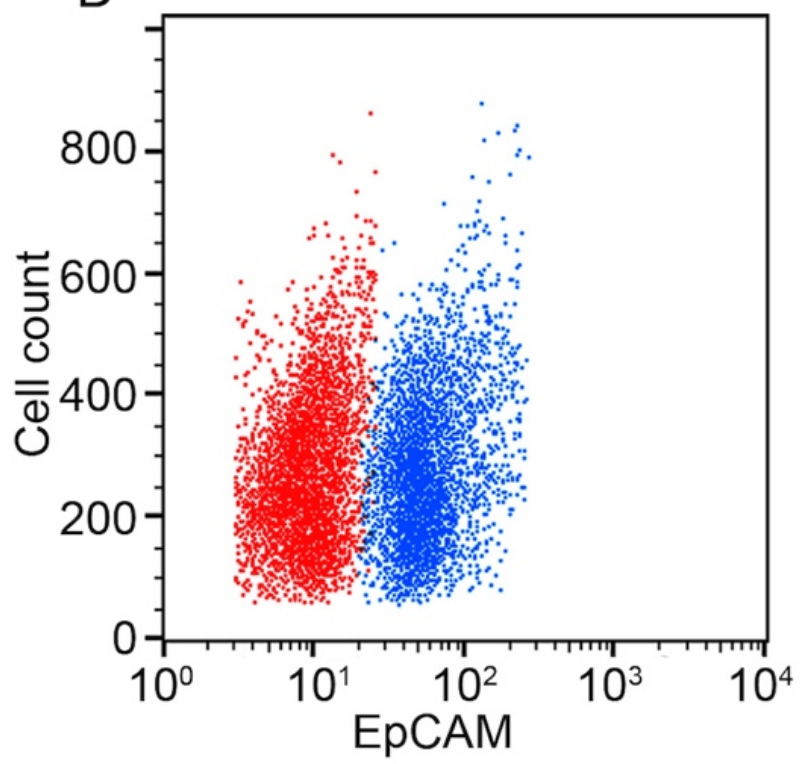

C
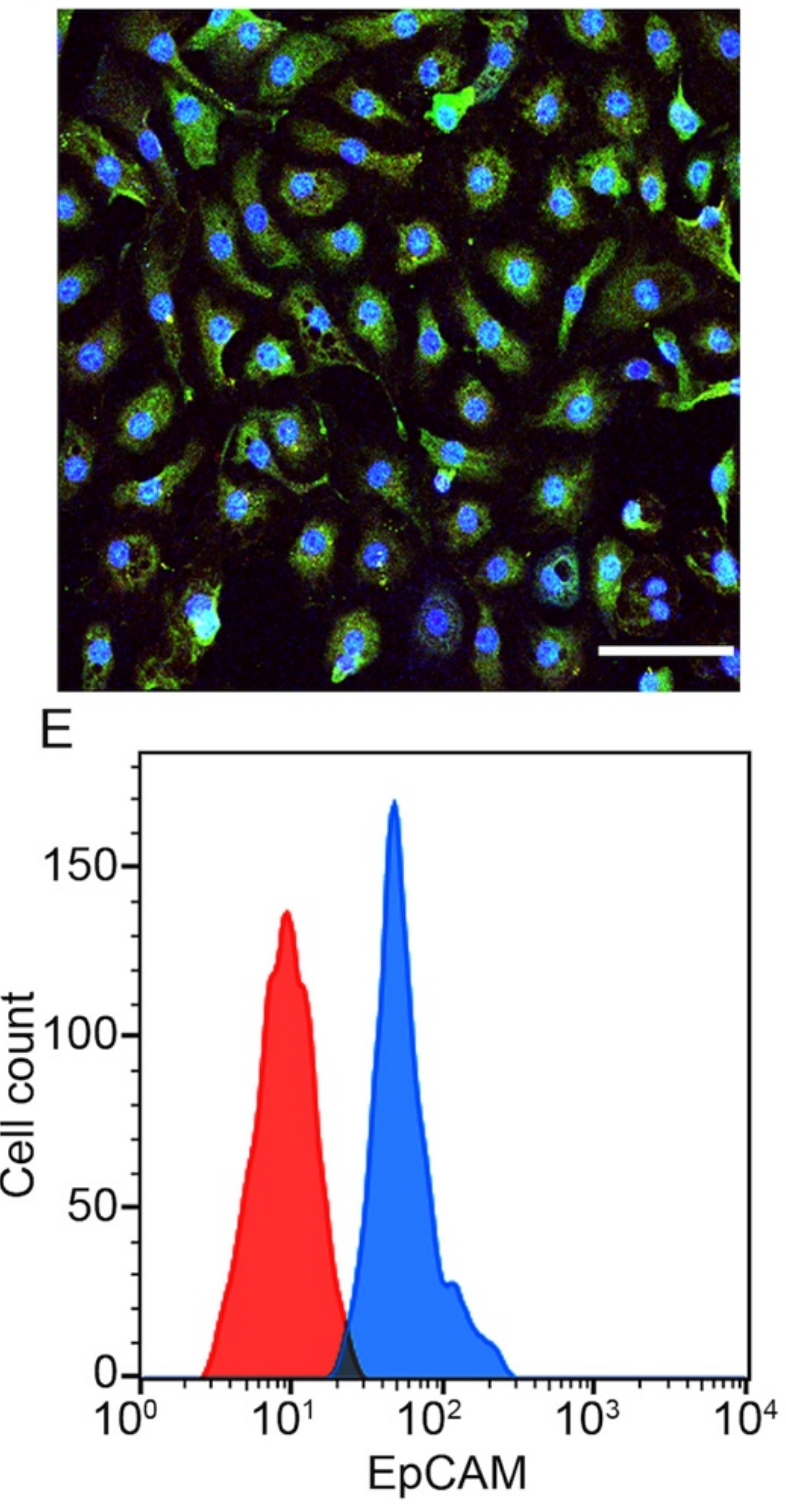
Supplementary file

Figure S2.
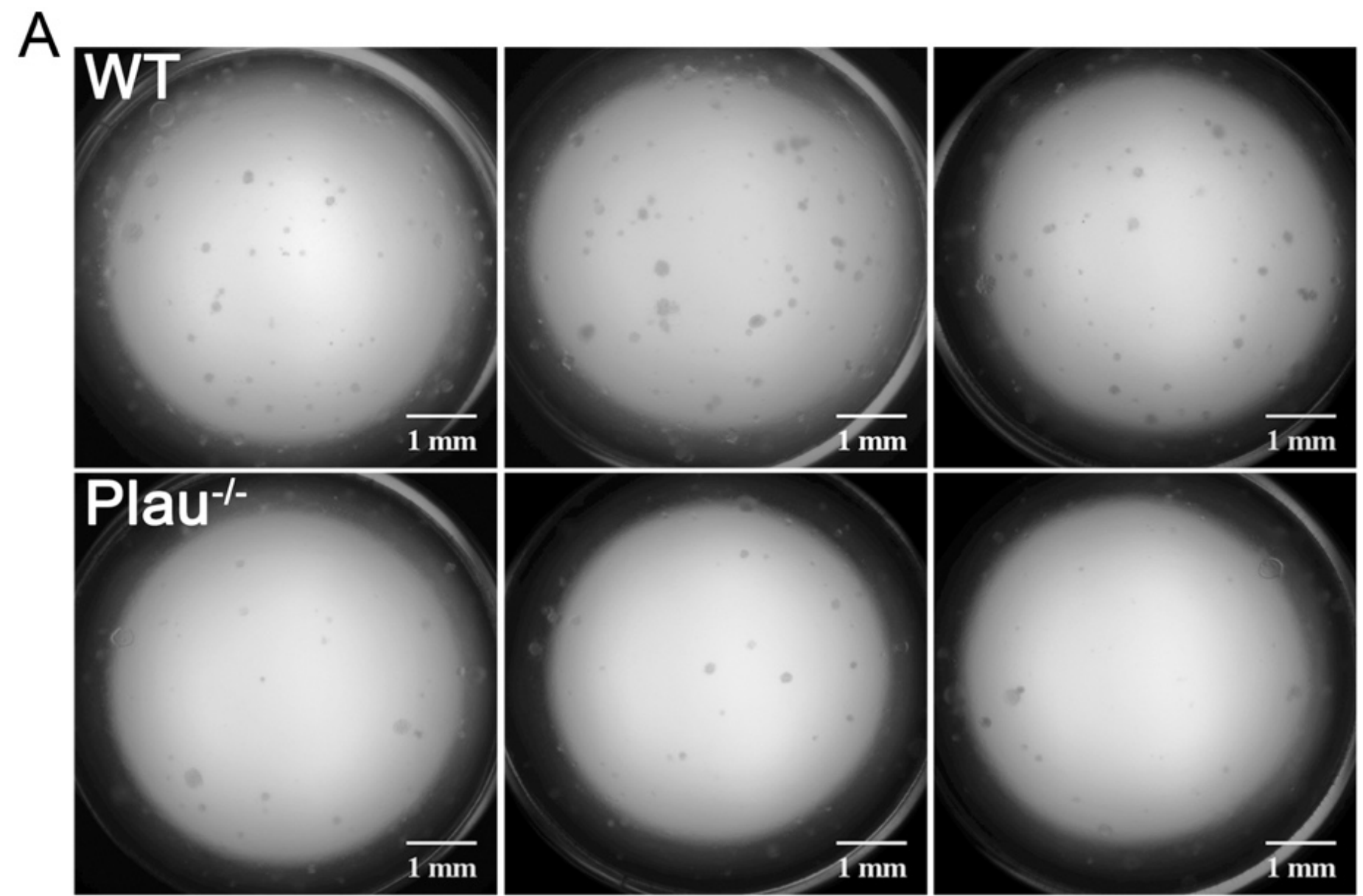
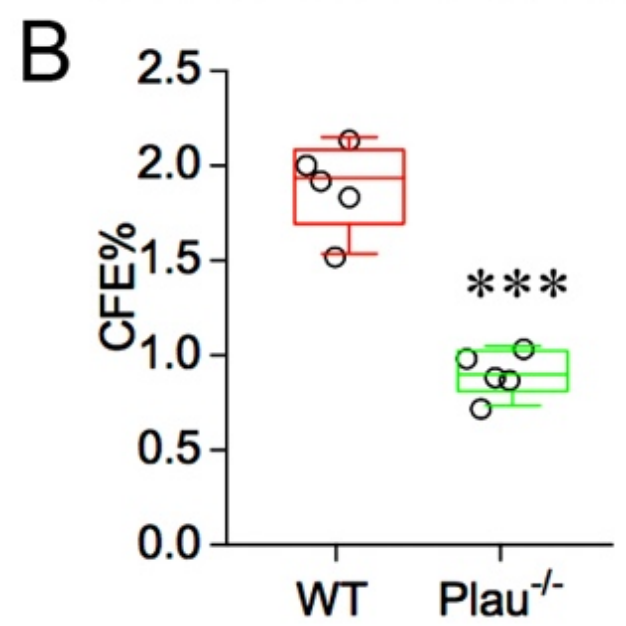
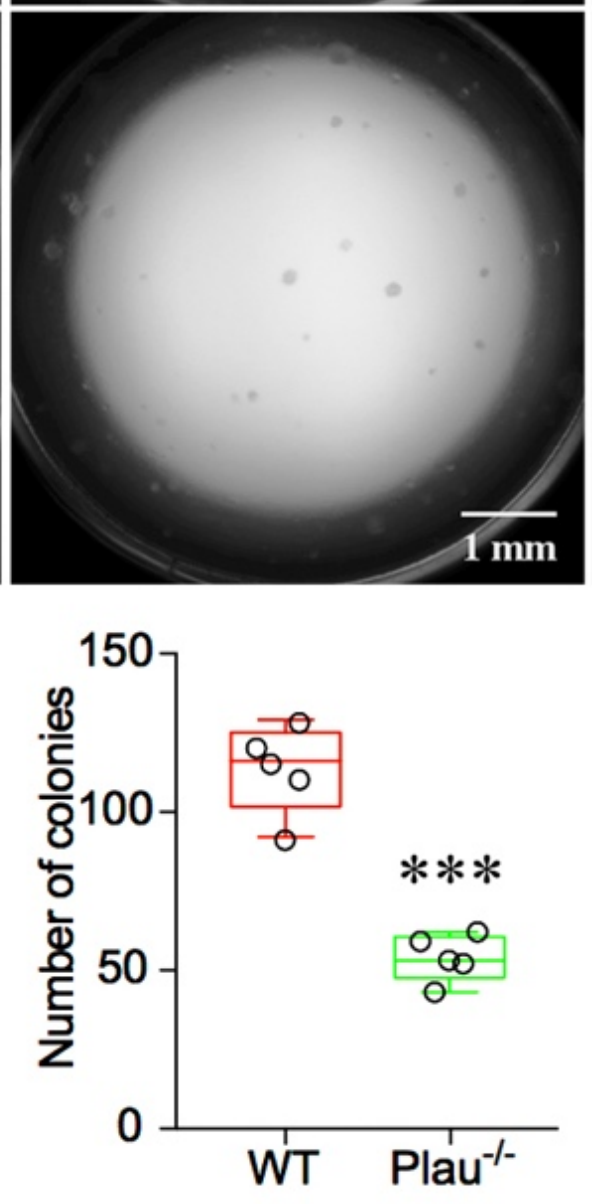
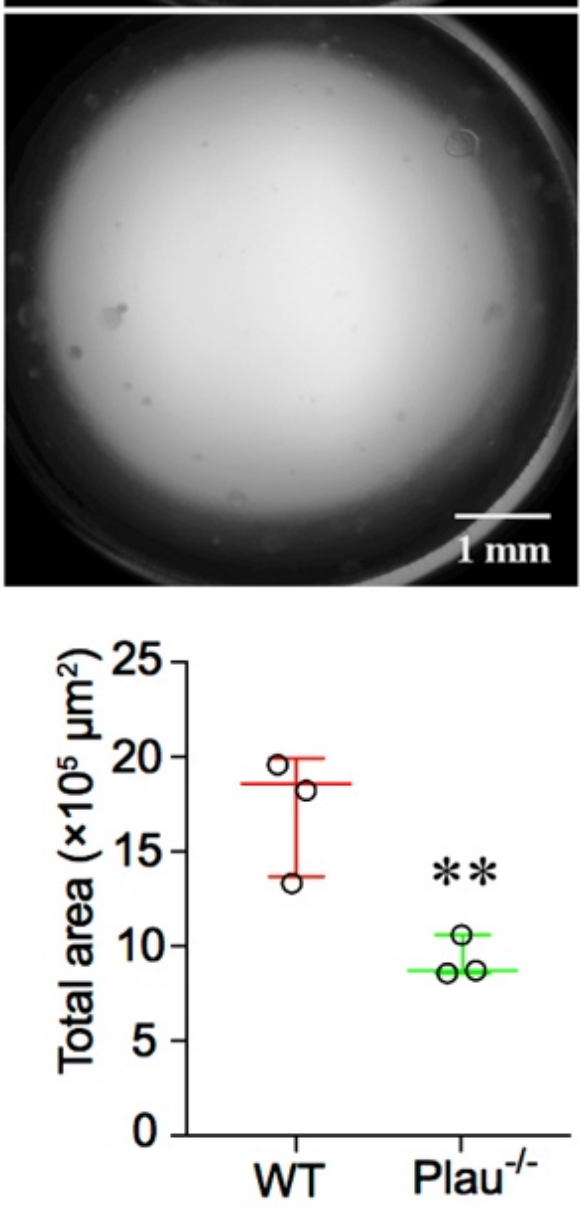
Supplementary file

\section{Figure S3.}

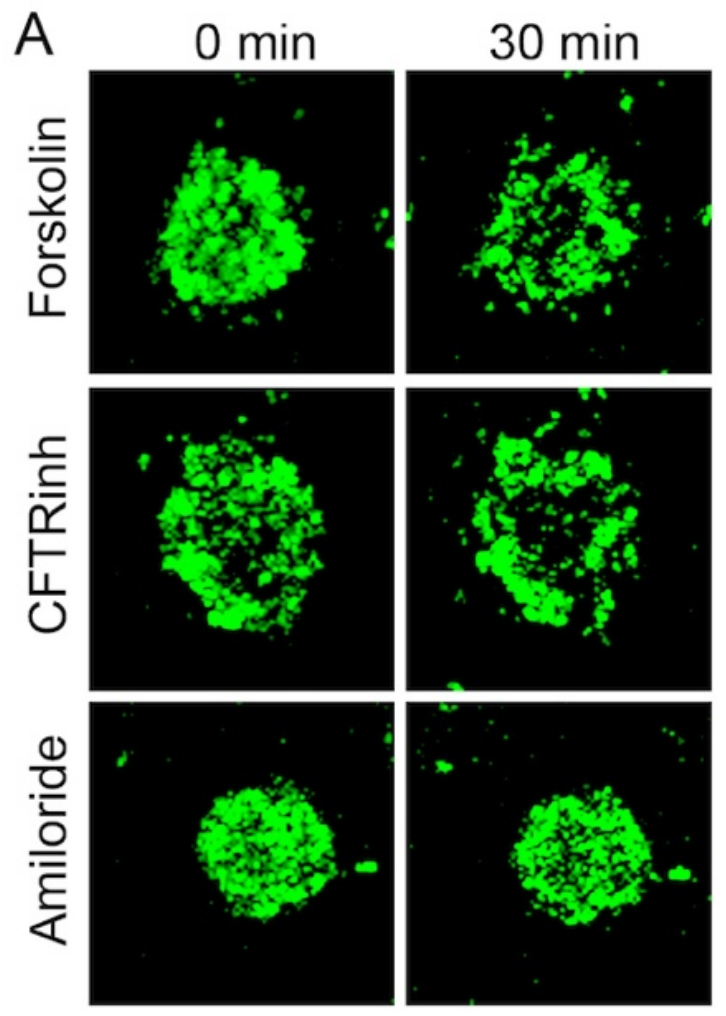

B

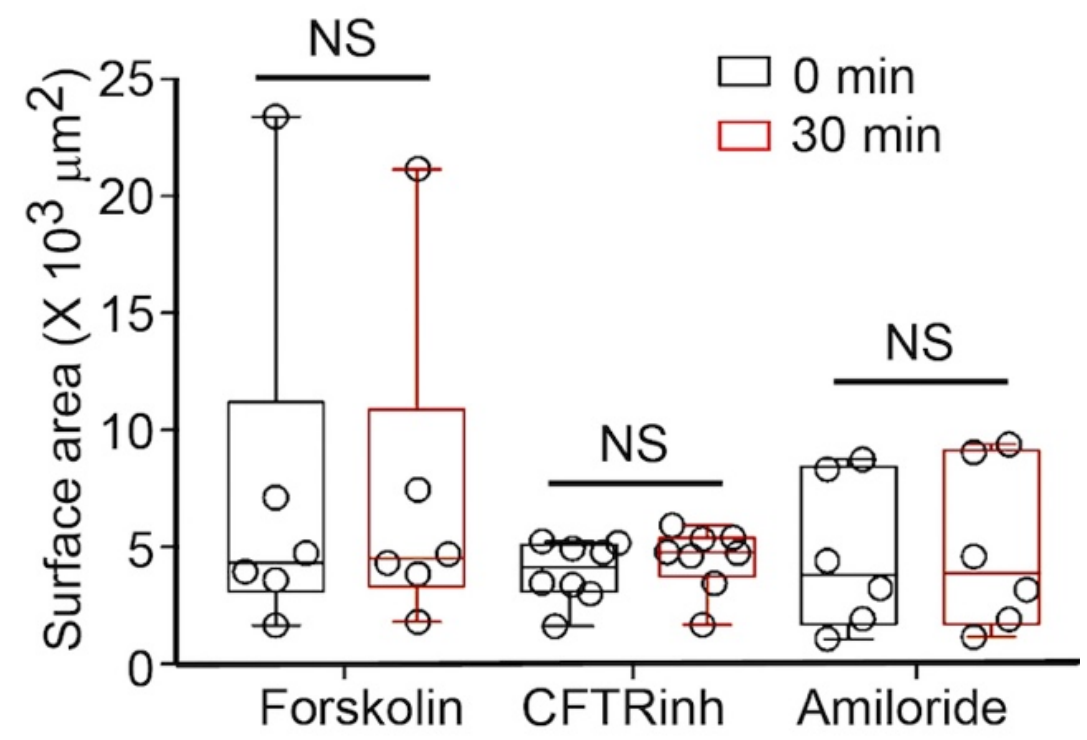




\section{Supplementary file}

\section{Figure S4.}
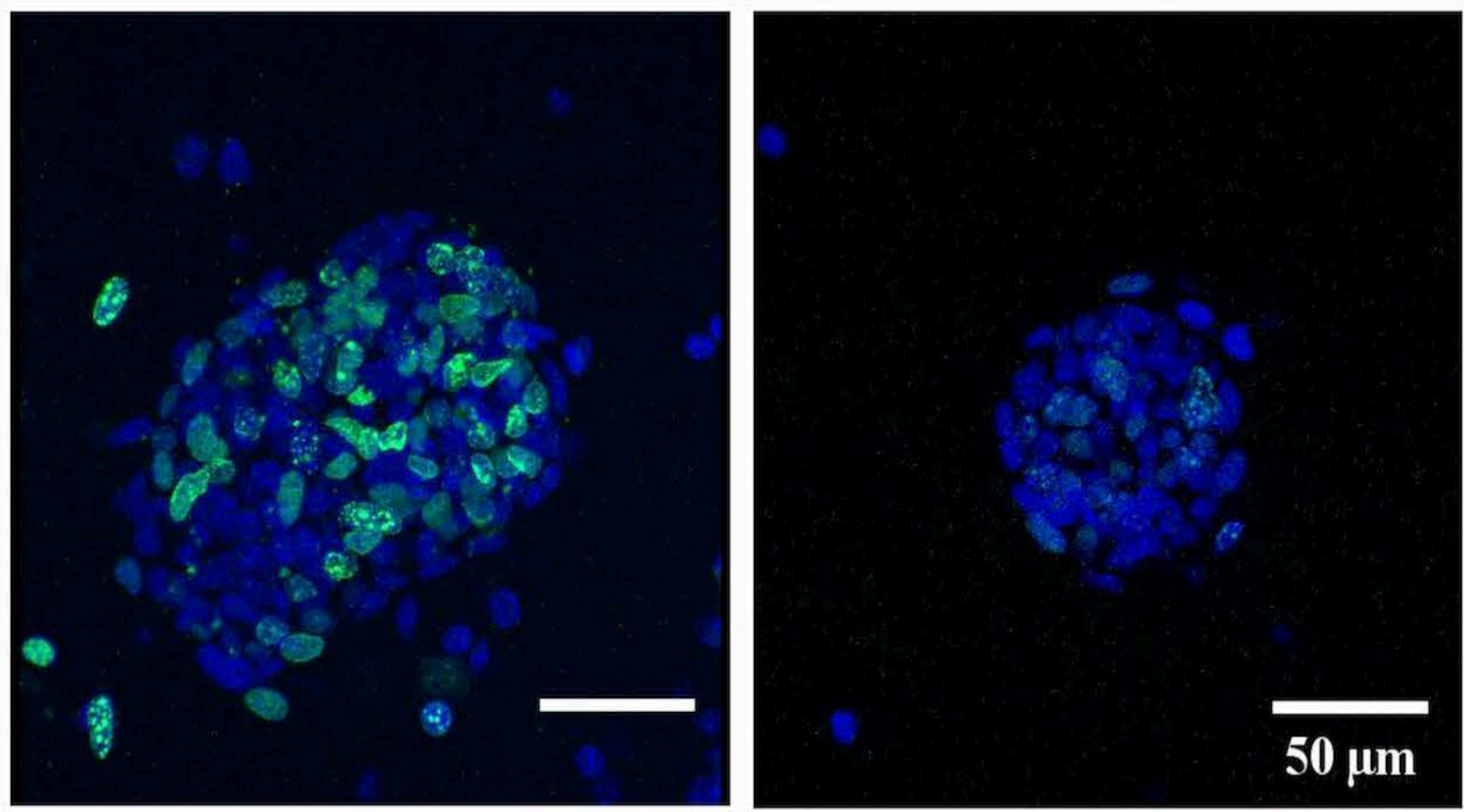
Supplementary file

Figure S5.

A
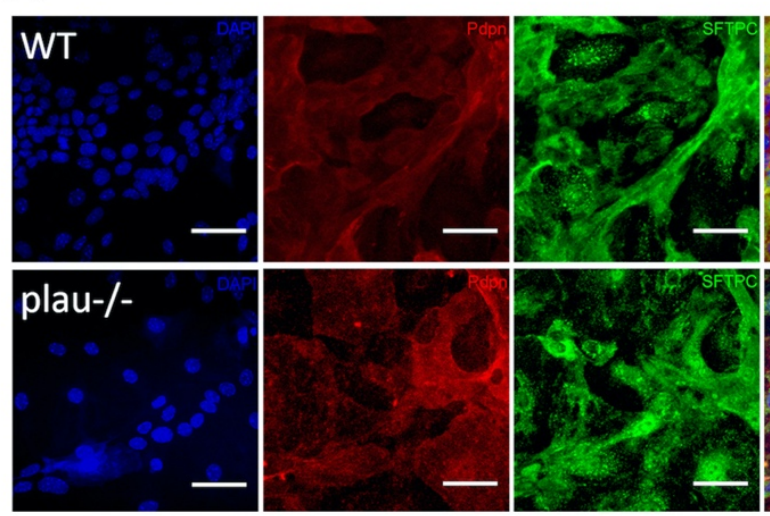

C

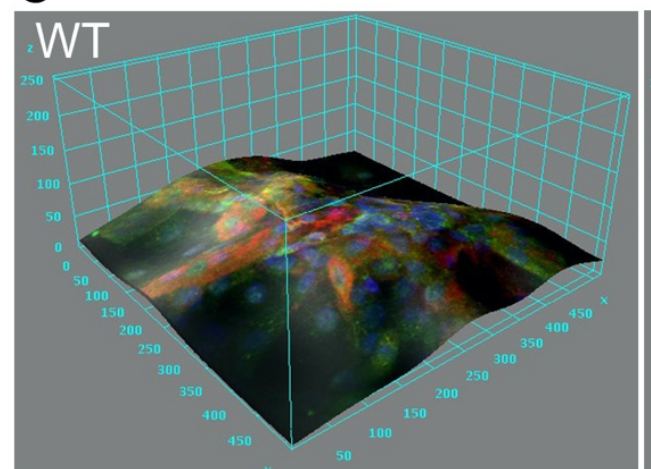

D

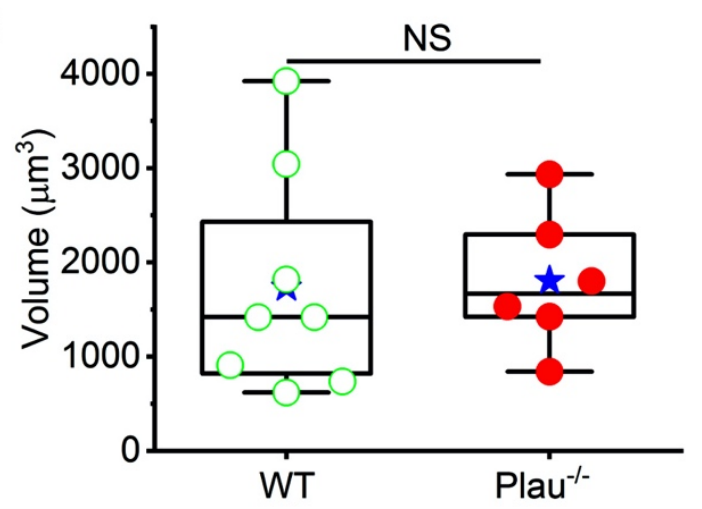

B
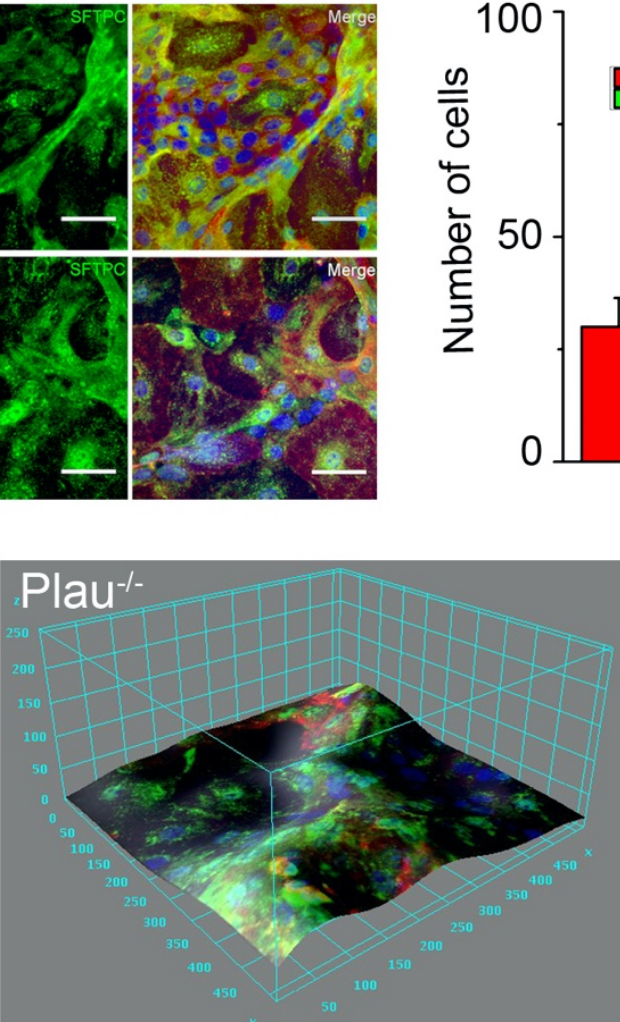

E

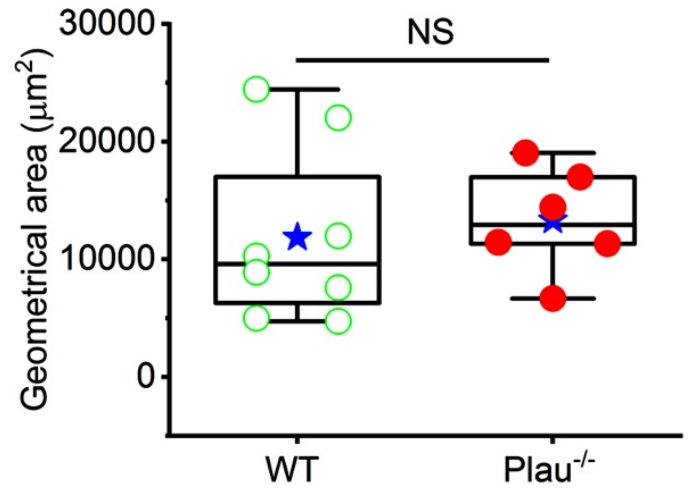


Supplementary file

Figure S6.
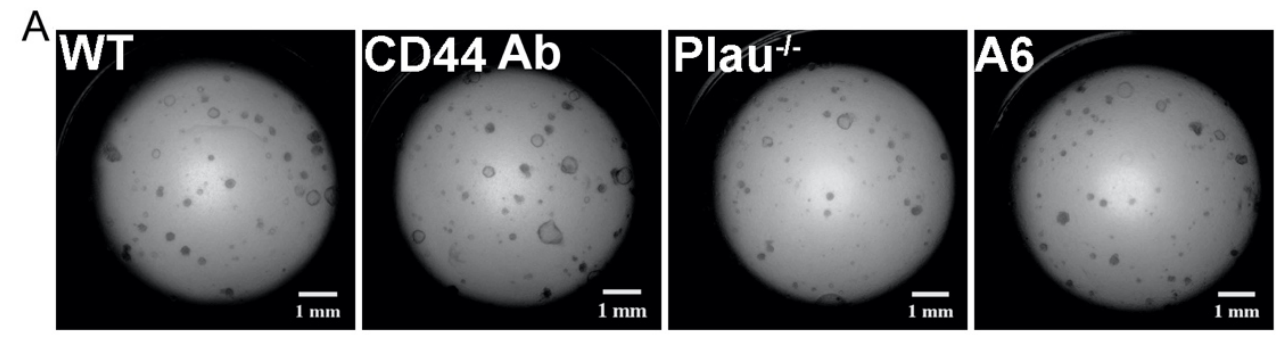

B

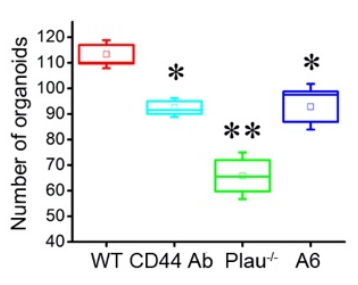

C

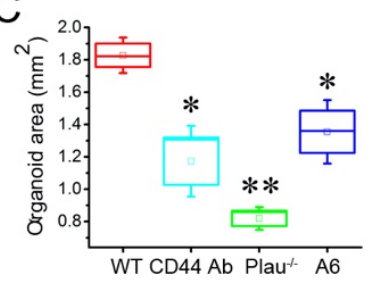

